\title{
GLUCOSINOLATES AND GLUCOSINOLATE DERIVATIVES: IMPLICATIONS FOR PROTECTION AGAINST CHEMICAL CARCINOGENESIS
}

\section{LIONELLE NUGON-BAUDON* AND SYLVIE RABOT}

Unité d'Ecologie et de Physiologie du Système Digestif, Centre de Recherches de Jouy, Institut National de la Recherche Agronomique, 78352 Jouy-en-Josas Cédex, France

\section{CONTENTS}

GLUCOSINOLATES: OCCURRENCE AND METABOLIC FATE . . . . 205

GLUCOSINOLATES IN THE PLANT . . . . . . . . . . . . 205

GENESIS OF GLUCOSINOLATE DERIVATIVES . . . . . . . . . 207

Enzymic hydrolysis and autolysis in cruciferous vegetables . . . . . . . . 207

Bacterial metabolism of glucosinolates . . . . . . . . . . . . . . $\quad$. $\quad$. 212

FROM THE PLANT TO THE DIET: INFLUENCE OF FOOD PROCESSING AND

DIETARY HABITS. . . . . . . . . . . . . . . 213

TOXICITY OF GLUCOSINOLATES AND GLUCOSINOLATE

DERIVATIVES .

GLUCOSINOLATES AND GLUCOSINOLATE DERIVATIVES: NEW

CANDIDATES FOR PROTECTION AGAINST CHEMICAL

CARCINOGENESIS

EPIDEMIOLOGICAL DATA: CRUCIFEROUS VEGETABLES AND CANCER INCIDENCE IN HUMAN POPULATIONS . . . . . . . . . . . . 217

EXPERIMENTAL DATA: CRUCIFEROUS VEGETABLES, GLUCOSINOLATES

AND CHEMICAL CARCINOGENS IN ANIMAL MODELS . . . . . . 217

EXPERIMENTAL DATA: CRUCIFEROUS VEGETABLES, GLUCOSINOLATES

AND XENOBIOTIC METABOLIZING ENZYMES . . . . . . . . 219

The xenobiotic metabolizing enzymes . . . . . . . . . . . . . . . 5219

The effects of cruciferous vegetables on the XME system . . . . . $\quad$. $\quad 220$

The effects of glucosinolates and glucosinolate derivatives on the XME system . 222 CONCLUSIONS AND PENDING TOPICS . . . . . . . . . . . 224 REFERENCES . . . . . . . . . . . . . . . . . . . . 225

\section{GLUCOSINOLATES: OCCURRENCE AND METABOLIC FATE}

\section{GLUCOSINOLATES IN THE PLANT}

Glucosinolates (GSL) are sulphur-containing molecules produced from amino acids by the secondary metabolism of plants. Their occurrence is limited to some families of dicotyledonous angiosperms. Considering edible plants only, they occur predominantly in Cruciferae and Capparideae and, sporadically, in Caricaceae and Tropaeolaceae (Table 1).

* Corresponding author. 
Table 1. Glucosinolate-containing edible plants

\begin{tabular}{|c|c|}
\hline 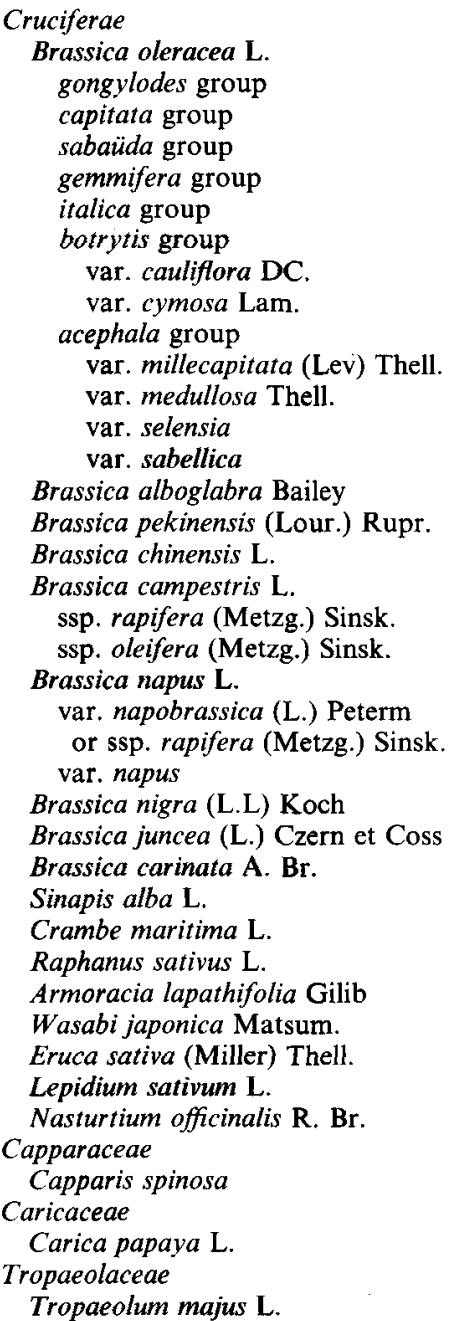 & $\begin{array}{l}\text { Kohlrabi } \\
\text { Red/white cabbage } \\
\text { Savoy cabbage } \\
\text { Brussels sprouts } \\
\text { Broccoli } \\
\text { Cauliflower } \\
\text { Calabrese (green sprouting broccoli) } \\
\text { Thousand head kale } \\
\text { Marrowstem kale } \\
\text { Curly kale } \\
\text { Collard } \\
\text { Chinese kale } \\
\text { Chinese cabbage (Pe-tsai) } \\
\text { Chinese white cabbage (Pak-choi) } \\
\text { Turnip } \\
\text { Turnip rape } \\
\text { Swede (Rutabaga) } \\
\text { Winter, summer rape } \\
\text { Black mustard } \\
\text { Brown mustard } \\
\text { Abysinian mustard (Ethiopian cabbage) } \\
\text { White mustard } \\
\text { Sea kale } \\
\text { Radish } \\
\text { Horseradish } \\
\text { Wasabi (Japanese horseradish) } \\
\text { Salad rocket } \\
\text { Garden cress } \\
\text { Water cress } \\
\text { Caper } \\
\text { Papaya (Pawpaw) } \\
\text { 'Nasturtium' (Indian cress) }\end{array}$ \\
\hline
\end{tabular}

References are: Carlson et al. (1981), Fenwick et al. (1982), Carlson et al. (1987), Adams et al. (1989).

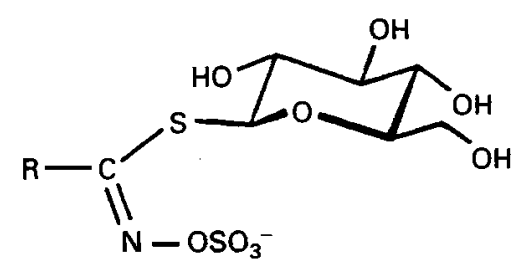

Fig. 1. The general structure of glucosinolates. 
Species belonging to these families are widely consumed by humans as cooked or salad vegetables (cabbage, Brussels sprouts, cauliflower, turnip, radish, cress) or condiments (horseradish, mustard, caper); cruciferous forages (kale, rape, turnip) and oilseed meals (rape, turnip rape) are used as feedstuffs for animals (Fenwick et al. 1982).

More than 100 different GSL, which all share a common structure (Fig. 1), have been identified so far (Fenwick et al. 1982). GSL may be classified into several chemical families according to their side groups R (Fenwick et al. 1986; Quinsac, 1993), which include alkyl, alkenyl, hydroxyalkyl, hydroxyalkenyl, methylthioalkyl, methylsulphinylalkyl, methylsulphonylalkyl, arylalkyl and indolyl groups (Table 2). Furthermore, a new family of GSL, designated cinnamoylGSL, was recently identified (Linscheid et al. 1980; Bjerg \& Sørensen, 1987). It differs from the usual pattern by the presence of cinnamic acid derivatives in the $\mathrm{C}(2)$ and/or $\mathrm{C}(6)$ positions on the glucose moiety.

Edible plants may contain up to fifteen different GSL. However, most of them synthesize between one and five of these compounds. Concern about the potential biological effects of GSL has in the last decade prompted various groups to examine the levels and profiles of these compounds in cruciferous vegetables. The reader interested in detailed information is referred to the extensive research performed at the Northern Regional Research Center of the US Department of Agriculture (Daxenbichler et al. 1979; Carlson et al. 1981, 1985, 1987) and at the Norwich Laboratory of the Institute of Food Research in Britain (Heaney \& Fenwick, $1980 a, b$; Fenwick et al. 1982; Sones et al. 1984a, b; Lewis \& Fenwick, 1987, 1988). Findings published by these and other workers are schematically summarized in Table 3. On the whole, great variations in the content as well as in the pattern of GSL occur according to the plant species. The wide range of GSL concentrations sometimes observed within an experiment and between different studies performed on the same vegetable indicates that further variations may occur according to the cultivar and the cultivation conditions. Carlson et al. (1985) have pointed out the remarkable differences in the GSL content between radishes originating from either the European-American or the Asian market. Analysis of Brussels sprouts and cauliflower cultivars grown at different sites in the UK shows great variations in the total GSL content (Heaney \& Fenwick, 1980a, b; Sones et al. 1984b); however, the relative proportions of the individual GSL tend to remain fairly stable within a cultivar. Climate, soil type and agronomic practices, especially fertilizer applications and harvest date, are cited as causative factors for such variations (Josefsson, 1970; Heaney \& Fenwick, $1980 a, b$; Fenwick et al. 1982; Lehrmann, 1989; Booth et al. 1990).

Another factor of tremendous importance is the part of the plant examined. Major quantitative and qualitative differences in the GSL accumulated by different organs (seeds, leaves, roots) and different tissues of the same organ (root peelings, cortex and medulla) occur in the same plant (Heaney \& Fenwick, 1980a, b; Sang et al. 1984; Carlson et al. 1987; Adams et al. 1989). Such findings highlight the point that GSL biosynthesis in the plant is probably ruled by complex control mechanisms and that one cannot extrapolate data available for one part of the plant to another tissue.

\section{GENESIS OF GLUCOSINOLATE DERIVATIVES}

\section{Enzymic hydrolysis and autolysis in cruciferous vegetables}

The breakdown of GSL by myrosinase, a specific plant hydrolytic enzyme (thioglucoside glucohydrolase $E C$ 3.2.3.1), has been extensively studied and reviewed (Duncan \& Milne, 1989).

In intact cruciferous tissues, the enzyme is stored separately from the GSL substrates in specific cells named idioblasts. Contact between the two will result from mechanical injury 
Table 2. Glucosinolates occurring in edible plants

\begin{tabular}{|c|c|c|}
\hline Side chain & Glucosinolate & Trivial name \\
\hline $\mathrm{CH}_{3-}$ & methyl- & glucocapparin \\
\hline $\mathrm{CH}_{3}-\mathrm{CH}_{2-}$ & ethyl- & glucolépidiin \\
\hline $\mathrm{CH}_{3}-\mathrm{CH}\left(\mathrm{CH}_{3}\right)-$ & iso-propyl- & glucoputranjivin \\
\hline $\mathrm{CH}_{3}-\mathrm{CH}_{2}-\mathrm{CH}\left(\mathrm{CH}_{3}\right)-$ & 1-methylpropyl- & glucocochlearin \\
\hline $\mathrm{CH}_{2}=\mathrm{CH}-\mathrm{CH}_{2}$ & prop-2-enyl- & sinigrin \\
\hline $\mathrm{CH}_{2}=\mathrm{CH}-\mathrm{CH}_{2}-\mathrm{CH}_{2}-$ & but-3-enyl- & gluconapin \\
\hline $\mathrm{CH}_{2}=\mathrm{CH}-\mathrm{CH}_{2}-\mathrm{CH}_{2}-\mathrm{CH}_{2-}$ & pent-4-enyl- & glucobrassicanapin \\
\hline $\mathrm{CH}_{2}=\mathrm{CH}-\mathrm{CH}(\mathrm{OH})-\mathrm{CH}_{2}-$ & $\begin{array}{l}\text { (R)-2-hydroxybut-3-enyl- } \\
\text { (S)-2-hydroxybut-3-enyl- }\end{array}$ & $\begin{array}{l}\text { progoitrin } \\
\text { epiprogoitrin }\end{array}$ \\
\hline $\mathrm{CH}_{2}=\mathrm{CH}-\mathrm{CH}_{2}-\mathrm{CH}(\mathrm{OH})-\mathrm{CH}_{2-}$ & (R)-2-hydroxypent-4-enyl- & gluconapoleiferin \\
\hline $\mathrm{CH}_{3}-\mathrm{S}-\mathrm{CH}_{2}-\mathrm{CH}_{2}-\mathrm{CH}_{2}-$ & 3-methylthiopropyl- & glucoiberverin \\
\hline $\mathrm{CH}_{3}-\mathrm{S}-\mathrm{CH}_{2}-\mathrm{CH}_{2}-\mathrm{CH}_{2}-\mathrm{CH}_{2}-$ & 4-methylthiobutyl- & glucoerucin \\
\hline $\mathrm{CH}_{3}-\mathrm{S}-\mathrm{CH}=\mathrm{CH}-\mathrm{CH}_{2}-\mathrm{CH}_{2}-$ & 4-methylthiobut-3-enyl- & glucoraphasatin \\
\hline $\mathrm{CH}_{3}-\mathrm{S}-\mathrm{CH}_{2}-\mathrm{CH}_{2}-\mathrm{CH}_{2}-\mathrm{CH}_{2}-\mathrm{CH}_{2}-$ & 5 -methylthiopentyl- & glucoberteroin \\
\hline $\mathrm{CH}_{3}-\mathrm{SO}-\mathrm{CH}_{2}-\mathrm{CH}_{2}-\mathrm{CH}_{2}-$ & (R)-3-methylsulphinylpropyl- & glucoiberin \\
\hline $\mathrm{CH}_{3}-\mathrm{SO}-\mathrm{CH}_{2}-\mathrm{CH}_{2}-\mathrm{CH}_{2}-\mathrm{CH}_{2}-$ & (R)-4-methylsulphinylbutyl- & glucoraphanin \\
\hline $\mathrm{CH}_{3-} \mathrm{SO}-\mathrm{CH}=\mathrm{CH}-\mathrm{CH}_{2}-\mathrm{CH}_{2-}$ & (R)-4-methylsulphinylbut-3-enyl- & glucoraphenin \\
\hline $\mathrm{CH}_{3}-\mathrm{SO}-\mathrm{CH}_{2}-\mathrm{CH}_{2}-\mathrm{CH}_{2}-\mathrm{CH}_{2}-\mathrm{CH}_{2}-$ & (R)-5-methylsulphinylpentyl- & glucoalyssin \\
\hline $\mathrm{CH}_{3}-\mathrm{SO}_{2}-\mathrm{CH}_{2}-\mathrm{CH}_{2}-\mathrm{CH}_{2}$ & 3-methylsulphonylpropyl- & glucocheirolin \\
\hline \multirow[t]{6}{*}{$\mathrm{CH}_{3}-\mathrm{SO}_{2}-\mathrm{CH}_{2}-\mathrm{CH}_{2}-\mathrm{CH}_{2}-\mathrm{CH}_{2-}$} & 4-methylsulphonylbutyl- & glucoerysolin \\
\hline & benzyl- & glucotropaeolin \\
\hline & 2-phenylethyl- & gluconasturtiin \\
\hline & $\begin{array}{l}\text { (R)-2-hydroxy-2-phenylethyl- } \\
\text { (S)-2-hydroxy-2-phenylethyl- }\end{array}$ & $\begin{array}{l}\text { glucobarbarin } \\
\text { glucosibarin }\end{array}$ \\
\hline & 3-hydroxybenzyl- & glucolepigramin \\
\hline & 4-hydroxybenzyl- & sinalbin \\
\hline ' $\mathbf{A I}$ & $\begin{array}{l}\text { indol-3-ylmethyl- } \\
\text { (R1=R4=H) } \\
1-\text { methoxyindol-3-ylmethyl- } \\
\text { (R1=OCH3 } ; R 4=H) \\
\text { 1-sulphoindol-3-ylmethyl- } \\
\left(R 1=\mathrm{SO}_{3}^{-} ; R 4=H\right) \\
\text { 4-hydroxyindol-3-ylmethyl- } \\
(R 1=H ; R 4=O H) \\
\text { 4-methoxyindol-3-ylmethyl- } \\
\left(R 1=H ; R 4=O H_{3}\right)\end{array}$ & $\begin{array}{l}\text { glucobrassicin } \\
\text { neoglucobrassicin } \\
\text { sulphoglucobrassicin } \\
\text { 4-hydroxyglucobrassicin } \\
\text { 4-methoxyglucobrassicin }\end{array}$ \\
\hline
\end{tabular}

References are: Fenwick et al. (1982), Quinsac (1993). 


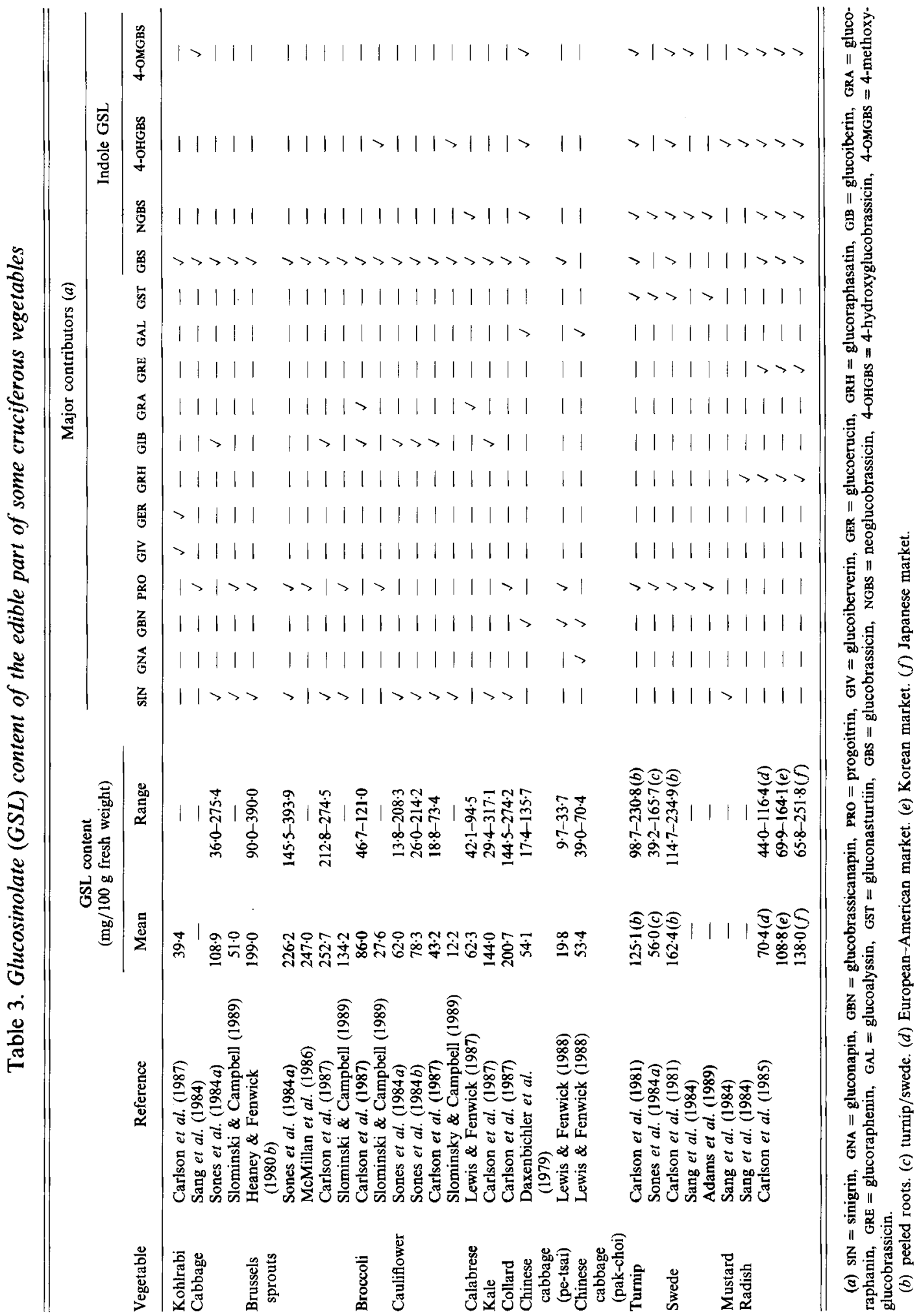




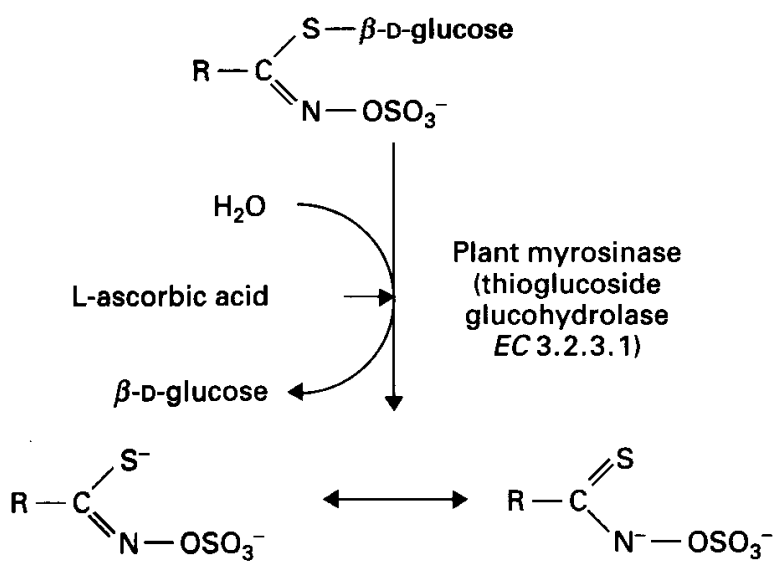

Thiohydroximate $-\mathrm{O}-$ sulphonates

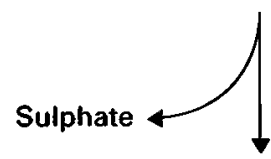

\begin{tabular}{ccc}
\hline $\begin{array}{c}\text { Isothiocyanates } \\
\mathrm{R}-\mathrm{N}=\mathrm{C}=\mathrm{S}\end{array}$ & $\begin{array}{c}\text { Nitriles } \\
\mathrm{R}-\mathrm{C} \equiv \mathrm{N}\end{array}$ & $\begin{array}{c}\text { Thiocyanates } \\
\mathrm{R}-\mathrm{S}-\mathrm{C} \equiv \mathrm{N}\end{array}$ \\
\hline cyano-epithioalkanes & oxazolidinethiones & $\mathrm{S}-\mathrm{C} \equiv \mathrm{N}^{-}$ \\
$(n=0,1,2)$ &
\end{tabular}

Fig. 2. The breakdown of glucosinolates by plant myrosinase.

of the plant tissue by, for example, cutting or chewing. Various isoenzymic forms of myrosinase have been isolated from different species and tissues (Fenwick et al. 1982; Buchwaldt et al. 1986). All of them hydrolyse the thioglucoside bond to release glucose and an unstable thiohydroximate- $O$-sulphonate, which is spontaneously further transformed (Lossen rearrangement; Ettlinger \& Lundeen, 1956) to yield sulphate and a wide range of aglucones including isothiocyanates, nitriles, epithioalkanes, oxazolidinethiones, thiocyanate anions and, occasionally, organic thiocyanates (Fig. 2).

The enzymic step of the breakdown is usually enhanced by ascorbic acid, which acts as a specific coenzyme (Ettlinger et al. 1961; Ohtsuru \& Hata, 1979). The structure of the aglucone eventually obtained is highly dependent on the structure of the side group $\mathrm{R}$ and on environmental factors such as $\mathrm{pH}$, metallic ions $\left(\mathrm{Fe}^{2+}, \mathrm{Fe}^{3+}, \mathrm{Cu}^{+}\right.$or $\mathrm{Cu}^{2+}$ ) (Tookey \& Wolff, 1970; Searle et al. 1984; Uda et al. 1986), and to a lesser extent temperature and moisture content (Tookey, 1973). For instance, low $\mathrm{pH}$, low temperature or metallic ions will favour nitrile production, whereas neutral $\mathrm{pH}$ or high temperature will push the reaction toward isothiocyanate release (VanEtten et al. 1966; Gil \& McLeod, 1980; Uda et al. 1986); the latter compound will tend to rearrange into oxazolidinethiones in an alkaline medium provided a hydroxyl group is present in the $\mathrm{C}(2)$ or $\mathrm{C}(3)$ position on the 


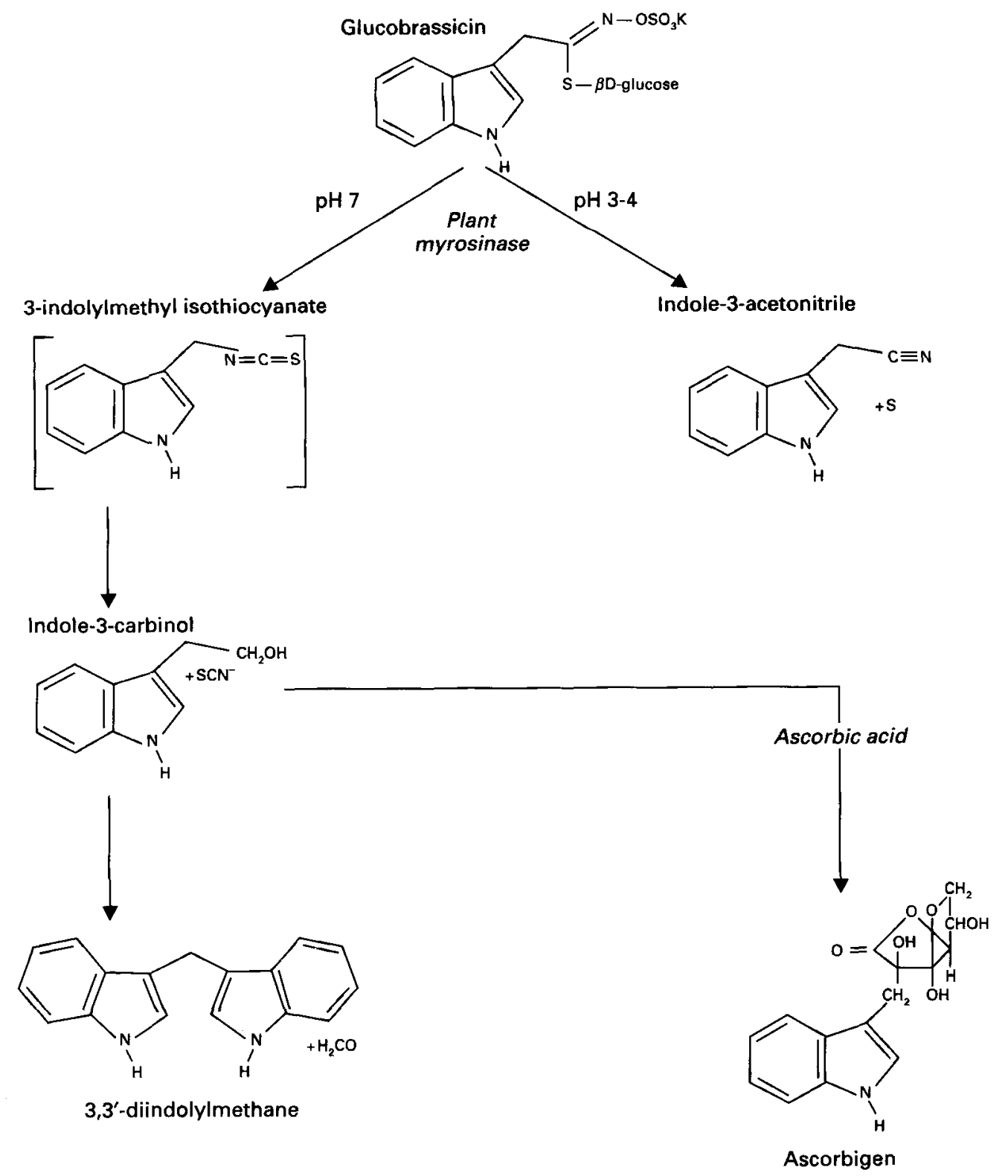

Fig. 3. The products of plant myrosinase hydrolysis of glucobrassicin.

side group R. Under the specific influence of ferrous ions autolysis can occur (Youngs \& Perlin, 1967; Austin et al. 1968).

IndolylGSL may follow different patterns of enzymic breakdown. Fig. 3 summarizes the hydrolysis of glucobrassicin. Depending on the environmental conditions, glucobrassicin hydrolysis leads to the formation of indole-3-acetonitrile (IAN) (acidic $\mathrm{pH}$, metallic ions) or of a putative unstable isothiocyanate derivative (neutral $\mathrm{pH}$ ) which splits immediately to yield a thiocyanate anion and indole-3-carbinol (I3C). In the absence of ascorbic acid, two molecules of I3C condense to yield 3,3'-diindolylmethane. Should ascorbic acid be 
present in the medium, it will react with $\mathrm{I} 3 \mathrm{C}$ to product ascorbigen (Searle et al. 1982). The glucobrassicin derivatives resulting from non-enzymic breakdown are different and vary with the $\mathrm{pH}$ : under acidic conditions, the first derivative would be IAN, thereafter transformed into indole-3-acetamide, indole-3-acetic acid and eventually skatole (minor product); a second pathway, which is less likely to occur, yields molecules such as indole3-carboxaldehyde, indole-3-carboxylic acid and indole (McDanell et al. 1988). On the whole, the variety of compounds arising from the indolylGSL breakdown is greater than that of the aglucones derived from other GSL molecules.

\section{Bacterial metabolism of glucosinolates}

The observation that GSL derivatives could occur in vivo without prior ingestion of myrosinase prompted Greer and coworkers to look for myrosinase-like activity in body tissues and fluids. The exciting story of the investigations that led them to postulate that the human intestinal microflora was able to hydrolyse GSL in vivo is recorded in a review by Greer (1962).

An in vitro myrosinase-like activity in rat (Greer, 1962) and fowl (Marangos \& Hill, 1974) faecal microflora was then demonstrated. Subsequently, different groups succeeded in isolating from human (Oginsky et al. 1965; Tani et al. 1974) and fowl (Miguchi et al. 1974) faecal microflora bacterial strains that were able to metabolize progoitrin or sinigrin in vitro.

Recent experiments performed with gnotobiotic animals in our laboratory at the Jouyen-Josas Research Centre of the National Institute for Agricultural Research (INRA) in France definitely demonstrated that the myrosinase-like activity of the intestinal microflora was physiologically relevant since biological effects of cruciferous vegetables never occurred in germ free rodents and chickens given a GSL-rich but myrosinase free feed (NugonBaudon et al. 1988).

So far bacterial myrosinase-like activity has been considerably underinvestigated. Evidence for 5-vinyloxazolidine-2-thione (a progoitrin derivative) was assessed by Greer \& Deeney (1959) in the urine of human volunteers after the ingestion of pure progoitrin, and by Oginsky et al. (1965) in the culture media of human Enterobacteriaceae strains incubated with the progoitrin. However, the breakdown of GSL by microflora is likely to be more complex than hydrolysis performed by the plant myrosinases. Experiments with gnotobiotic animals support the hypothesis that bacteria yield specific toxic GSL derivatives (Rabot $e t$ al. 1993a). Further conversion of several GSL derivatives into unknown compounds has been demonstrated in sheep rumen fluid in vitro (Lanzani et al. 1974; Duncan \& Milne, 1992). There is little other information: the salient points in the studies of Oginsky et al. (1965) and Tani et al. (1974) are the influence of $\mathrm{pH}$ and the lack of influence, or even inhibitory effect, of ascorbic acid on bacterial myrosinase-like activities in vitro. In vivo, manipulation of the mineral (Vermorel \& Evrard, 1987) or carbohydrate (Rabot et al. 1991) fraction of the diet helped to reduce the biological effects of cruciferous vegetables, implying that the bacterial myrosinase-like activities were altered in some way.

Improved and extended information on the myrosinase-like activities of the intestinal microflora would be of tremendous importance since plant myrosinase can be inactivated during processing of cruciferous vegetables; the implication is that a significant proportion of GSL must be actually metabolized by the intestinal microflora. 


\section{FROM THE PLANT TO THE DIET: INFLUENCE OF FOOD PROCESSING AND DIETARY HABITS}

When one knows the basic GSL content of cruciferous edible plants, it does not mean that one has reached the end of the story. Before being consumed, cruciferous vegetables usually undergo processing operations that may influence the GSL content. De Vos \& Blijleven (1988) have extensively reviewed this subject and we report here only the main points relevant to the discussion in subsequent sections of the present review.

Basic processes such as dicing, slicing, or shredding raw vegetables initiate the breakdown of GSL by myrosinase, since rupture of tissues puts the enzyme into contact with its substrates. However, some intact GSL may remain, depending on the degree of crushing (de Vos \& Blijleven, 1988). Pulping might of course be expected to result in a high degree of GSL breakdown. Indeed no intact GSL can be recovered from homogenized cabbage (de Vos \& Blijleven, 1988) and Brussels sprouts (Bradfield \& Bjeldanes, 1987) after $30 \mathrm{~min}$ and $24 \mathrm{~h}$ respectively. A preponderance of nitrile derivatives and, from indolylGSL, of ascorbigen and $\mathrm{I3C}$ have been identified, although the latter compound is not particularly stable and tends to undergo conversion into other products, mainly ascorbigen. Thus McDanell et al. (1987) have shown that the concentration of ascorbigen in Savoy cabbage homogenized to a thick slurry prior to deep-freezing and freeze-drying was $1.5 \mathrm{~g} / \mathrm{kg}$ dry matter; this level represents $75 \%$ of the theoretical total of breakdown products, based on the glucobrassicin content.

Cooking, steaming and blanching usually reduce GSL concentrations by $30-60 \%$, depending on the vegetable and on the type of GSL (Sones et al. 1984a); the loss is due partly to enzymic hydrolysis and partly to leaching of the intact GSL and their derivatives into the cooking liquid (Srisangnam et al. 1980 b; Slominski \& Campbell, 1989). The pattern of intact GSL and breakdown products recovered after cooking is influenced by the thermal stability of the molecules: sinigrin, for instance, is more thermostable than progoitrin or glucoiberverin, allyl isothiocyanate (from sinigrin) totally disappears upon boiling, while 5-vinyloxazolidine-2-thione (from progoitrin) and 3-methyl-sulphinylpropylisothiocyanate (from glucoiberin) may partly escape decomposition (de Vos \& Blijleven, 1988). Once again, among glucobrassicin derivatives, ascorbigen appears to be the major compound recovered after cooking (McDanell et al. 1987).

Fermented cruciferous products (sauerkraut, salt fermented vegetables) contain no intact GSL since this kind of process favours their quick and complete enzymic hydrolysis. In a study by Daxenbichler et al. (1980), reported by de Vos \& Blijleven (1988), the main GSL derivatives identified in sauerkraut after a 2 week fermentation were the thiocyanate anion and 1-cyano-3-methylsulphinylpropane (a nitrile from glucoiberin). However McDanell et al. (1987) found that fermentation $\left(18 \mathrm{~h}, 25^{\circ} \mathrm{C}\right)$ of white or Savoy cabbage was less detrimental to intact GSL than cooking; as far as GSL derivatives were concerned, the content of IAN was seldom modified by fermentation whereas there was an important decrease of ascorbigen compared with the fresh material.

Storage processes such as freezing, dehydrating or irradiating have received much less attention. From the few and often contradictory studies reported, one can conclude only that whereas dehydrating preserves intact GSL (de Vos \& Blijleven, 1988), irradiation with u.v. or ionizing radiation tends to favour their breakdown (Michajlovskij, 1968 cited in McDanell et al. 1988; Nugon-Baudon et al. 1988; de Vos \& Blijleven, 1988).

Table 4 reports the average consumption of cruciferous vegetables in several countries for which nutritional survey data are available. While cruciferous vegetables are consumed worldwide, this table highlights the fact that quantitative and qualitative differences occur between the geographical regions and/or the dietary habits characteristic of each country. 
Table 4. Average weekly intake of some cruciferous vegetables in the UK, USA, Canada and Japan ( $g /$ person)

\begin{tabular}{llcccc}
\hline \hline Vegetables & $\begin{array}{c}\text { UK } \\
(1980)\end{array}$ & $\begin{array}{c}\text { USA } \\
(1978)\end{array}$ & $\begin{array}{c}\text { Canada } \\
(1978)\end{array}$ & $\begin{array}{c}\text { Japan } \\
(1975)\end{array}$ \\
\hline Cabbage & $123 \cdot 2$ & $77 \cdot 0$ & $34 \cdot 2$ & $136 \cdot 5$ \\
Brussels sprouts & $67 \cdot 9$ & $2 \cdot 1$ & $5 \cdot 2$ & - \\
Broccoli & - & $23 \cdot 1$ & $14 \cdot 1$ & - \\
Cauliflower & $71 \cdot 4$ & $14 \cdot 0$ & $9 \cdot 4$ & - \\
Chinese cabbage & - & - & $0 \cdot 4$ & $159 \cdot 6$ \\
Turnip/Swede & $38 \cdot 5$ & - & $24 \cdot 6$ & - \\
Mustard & - & - & $8 \cdot 3$ & - \\
Radish & - & - & $7 \cdot 2$ & $232 \cdot 4$ \\
Coleslaw & - & - & $14 \cdot 3$ & - \\
Sauerkraut & - & $11 \cdot 2$ & $\mathbf{6 \cdot 7}$ & - \\
& Salt fermented vegetables & - & - & - & $260 \cdot 4$ \\
\hline \hline
\end{tabular}

References are: Benns et al. (1978), Fenwick et al. (1982), Sones et al. (1984a).

Table 5. Average weekly intake of glucosinolates from fresh vegetables in the UK and Canada

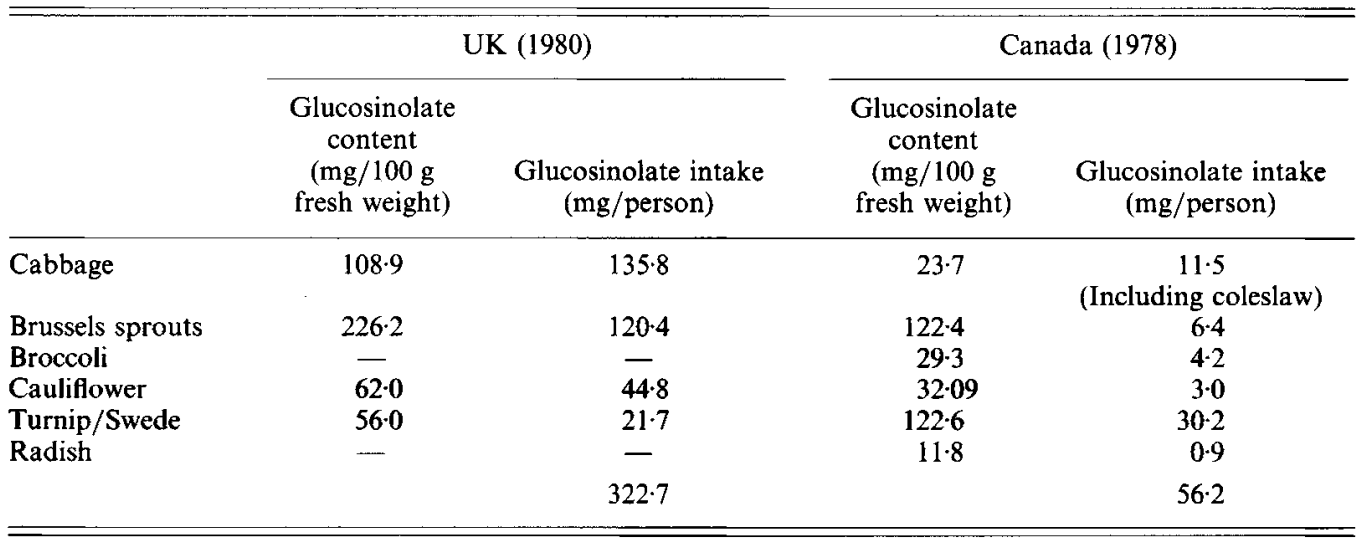

References are: Mullin \& Sahasrabudhe (1978), Sones et al. (1984a).

Living standards may also account for variations in cruciferous vegetable consumption; as the income increases, there is an increase in total fresh green vegetable consumption (Sones et al. 1984a) and, among them, mild flavoured vegetables such as cauliflower or calabrese are preferred to cabbage or kale (Crisp, 1976 cited in Lewis \& Fenwick, 1987). Sones et al. (1984a) and Mullin \& Sahasrabudhe (1978) have estimated, from the British and Canadian consumption data reported in Table 4, the average intake of GSL in British and Canadian populations respectively. Assuming that the vegetables were eaten raw, the mean daily intakes were calculated to be $8 \cdot 0$ and $46.1 \mathrm{mg}$ respectively in Canada and the UK (Table 5). Figures for individual GSL or GSL derivatives have occasionally been reported by some authors; the intake of progoitrin in the average UK diet is approximately $7 \mathrm{mg} / \mathrm{day}$ (Fenwick et al. 1983) and an average level of $28 \mu \mathrm{mol}$ of glucoiberin is reported to be ingested daily by US citizens (Kore et al. 1993). Although this kind of information is very useful to draw a picture of levels of GSL ingested by humans, it must be treated with extreme caution since the final GSL and GSL derivative content of a dietary cruciferous 
vegetable depends on a tremendous number of factors. The researchers were of course aware of this uncertainty; indeed Sones et al. (1984a) have estimated that the amount of GSL ingested by certain individuals could exceed $300 \mathrm{mg} /$ day.

On the whole, the findings reported here on GSL content of cruciferous vegetables and subsequent GSL consumption demonstrate that investigations about the biological effects of GSL should include measurement of, at the very least, the total GSL content and, ideally, of the content of individual GSL and hydrolysis products of the cruciferous vegetable included in the experimental diets. In addition, detailed information on how the cruciferous material and food are processed should also be provided; this should help nutritionists and toxicologists to obtain more valuable information from studies in which the experimental diets are inevitably different. Furthermore, if estimated figures for GSL consumption are helpful tools for the design of experimental diets, one should keep in mind that tremendous quantitative and qualitative variations occur in GSL consumption by humans.

\section{TOXICITY OF GLUCOSINOLATES AND GLUCOSINOLATE DERIVATIVES}

GSL derivatives are now known to be the toxic principles of cruciferous vegetables, and their toxic effects are well documented, especially in the case of rapeseed meal. Summarizing the vast literature published on this issue would be far too long; we have therefore stressed only the most striking points.

Experimentally, the general phenomenon observed is impaired performance of animals consuming GSL-rich feeds. The gross toxic effects can be described as reduced feed intake, growth depression, enlargement of target organs (liver, kidneys, thyroid gland) and reproductive disorders such as embryo mortality in mammals and decreased egg production in birds. The intensity of these effects varies with the animal species and, of course, the amount of GSL in their food (Bourdon et al. 1981; Butler et al. 1982; Bell, 1984; Vermorel et al. 1987; Etienne \& Dourmad, 1987). In humans, reduced iodine uptake by the thyroid gland was reported after daily ingestion of $500 \mathrm{~g}$ cabbage for 2 weeks (Langer et al. 1971) or after a single meal of 300 to $500 \mathrm{~g}$ swede or turnip (Greer \& Astwood, 1948). However, a more recent study by McMillan et al. (1986) did not lead to hypothyroidism in human volunteers consuming $150 \mathrm{~g}$ Brussels sprouts daily for 4 weeks. Nevertheless these contradictory findings are not too puzzling, since the thyroid function indices that were examined and the cruciferous vegetables and their GSL that were ingested were not the same.

Several attempts have been made to ascertain precisely which GSL or GSL derivatives are responsible for the different components of GSL toxicity. Addition of pure sinigrin or gluconapin to the diet led to liver hypertrophy in rats. Progoitrin seems to have a greater toxic potential; it has been shown to induce enlargement of the liver, kidneys and thyroid in rats (Bille et al. 1983; Vermorel et al. 1986). Goitrin (5-vinyloxazolidine-2-thione), one of the major derivatives of progoitrin, has been the most extensively studied GSL derivative, as far as toxicity is concerned. This goitrogen, very potent even at low doses (Krusius \& Peltola, 1966; Langer \& Michajlovskij, 1969; Akiba \& Matsumoto, 1976), can induce decreased uptake of iodine by the thyroid gland in humans (Astwood et al. 1949) and in rats, modify the triiodothyronine: thyroxine ratio and alter the histological pattern of the thyroid in rats (Lo \& Hill, 1971; Bell et al. 1972; Lo \& Bell, 1972). It seems that goitrin interferes with organic iodination of thyroxine precursors in the gland, thus leading to compensatory goitre (Akiba \& Matsumoto, 1976; Elfving, 1980). Isothiocyanates and thiocyanates were held responsible for similar thyroid disorders (Langer, 1964 cited in 
Duncan \& Milne, 1989; Langer \& Štolc, 1965). The former prevent the iodination of tyrosine, as does goitrin, whereas the latter are known competitively to inhibit iodine uptake by thyroid cells (Langer \& Greer, 1968; Muztar et al. 1979). Sinigrin and glucoiberin isothiocyanate derivatives were also shown to induce embryo death in the rat but the mechanism is still unknown (Nishie \& Daxenbichler, 1980). Preferential target organs of the nitrile derivatives seem to be the liver and kidneys (VanEtten et al. 1969; Srivastava et al. 1975). The mechanism that underlies their toxicity seems to be their ability to interact with reduced glutathione, thus leading to substantial alterations in tissue glutathione levels as observed by Szabo et al. (1977) in the liver, kidneys, adrenals and lungs of rats after chronic ingestion or a single injection of acrylonitrile. The toxic effect of nitriles manifests itself as hypertrophy of the target organs, disruption of the normal lobular structure of the liver and irregular proliferation of the bile duct (VanEtten et al. 1969). As far as kidneys are concerned, enlarged nuclei of the epithelial cells lining the convoluted tubules have been observed (VanEtten et al. 1969). Gould et al. (1985) observed rapid production of kidney lesions, along with elevated plasma levels of nitrogen, urea and creatinine, which could suggest functional alterations of the kidneys.

Investigating the nature and the underlying mechanisms of toxic effects induced by GSL derivatives released by plant myrosinase gives very valuable information. However, it does not take into account the ability of the intestinal microflora to break down intact GSL or their derivatives into metabolites of which the nature and specific toxic potential are so far largely unknown. Experiments with gnotobiotic animals have proved to be an invaluable tool for addressing this topic. Those performed in our laboratory suggest that the different toxic patterns usually observed in different animal species are more likely to be due to differences in the autochthonous digestive microflora than to intrinsic host sensitivity toward GSL. Indeed, when given a diet based on rapeseed meal, conventional rats exhibit GSL-linked symptoms different from those of gnotobiotic rats harbouring either chicken or human microflora (Nugon-Baudon et al. 1988; Rabot et al. 1993a). The inoculation of germ free rats with single strains of fowl or human origin provided further information about the role of intestinal microflora in the production of toxic GSL derivatives. The toxic effects, observed in rats associated with a whole human microflora, namely reduced feed intake and weight gain, enlargement of the liver and thyroid and a decrease in both thyroxine (T4) and triiodothyronine (T3) plasma levels, could be reproduced in gnotobiotic rats harbouring a single human strain of Bacteroides vulgatus (Rabot et al. 1993a). Eventually, such simplified gnotobiotic models enabled our group to split the toxicity observed with complex intestinal microflora into different patterns (Table 6). A Lactobacillus strain isolated from a chicken crop was shown to induce goitre in gnotobiotic rats given a diet based on rapeseed meal (Nugon-Baudon et al. 1990b) whereas human strains of Clostridium butyricum and Escherichia coli, each isolated from healthy individuals, were responsible for liver hypertrophy and goitre associated with reduced T4 and T3 plasma levels respectively (Rabot et al. 1991, 1993a).

These findings reinforce the idea that, should the plant myrosinase in the diet be totally inactivated, the toxicity of GSL would depend strictly on the equilibrium between bacterial species possessing specific myrosinase-like activities. There exists an overall similarity in the nature of toxic effects observed in conventional rats given either pure GSL derivatives produced by plant myrosinase or a GSL-rich but myrosinase free diet. Nevertheless, one cannot exclude the possibility that extra metabolites, toxic or non-toxic, may be produced either from intact GSL or from previously released derivatives. This would of course enhance the difficulty that one encounters when trying to infer the potential toxicity of a diet containing cruciferous vegetables from a knowledge of its GSL and GSL derivative content. 
Table 6. Effects of a diet with rapeseed meal on weight gain, organ weight and thyroid hormones in gnotobiotic rats according to their bacterial status

(Results are expressed as \% of the mean values obtained with counterpart rats given a diet with soyabean meal)

\begin{tabular}{|c|c|c|c|c|}
\hline Bacterial strain... & $\begin{array}{l}\text { Lactobacillus (a) } \\
\text { (LEM } 220 \text { strain) }\end{array}$ & $\begin{array}{c}\text { Bacteroides } \\
\text { vulgatus (b) } \\
\text { (BV8H l strain) }\end{array}$ & $\begin{array}{c}\text { Clostridium } \\
\text { butyricum }(\mathrm{b}) \\
\text { (CB1002 strain) }\end{array}$ & $\begin{array}{c}\text { Escherichia } \\
\text { coli }(\mathrm{b}) \\
\text { (EM0 strain) }\end{array}$ \\
\hline Reference... & $\begin{array}{l}\text { Nugon-Baudon et al. } \\
(1990 b)\end{array}$ & $\begin{array}{l}\text { Rabot et al. } \\
\quad(1993 a)\end{array}$ & $\begin{array}{l}\text { Rabot et al. } \\
\quad(1990)\end{array}$ & $\begin{array}{l}\text { Rabot el al. } \\
\quad(1993 a)\end{array}$ \\
\hline $\begin{array}{l}\text { Duration of the trial } \\
\text { (weeks)... }\end{array}$ & 5 & 7 & 7 & 7 \\
\hline No. of animals... & 7 & 6 & 6 & 6 \\
\hline Cumulative weight gain & 109 & $28 * * *$ & 105 & 90 \\
\hline Liver & 106 & $114^{* * *}$ & $115^{* *}$ & 101 \\
\hline Kidneys & 99 & 113 & $108^{* *}$ & 95 \\
\hline Thyroid & $148 * * *$ & $672 * * *$ & 111 & $302 * * *$ \\
\hline Tetraiodothyronine & 112 & $57 * *$ & 95 & $56^{* * *}$ \\
\hline Triiodothyronine & ND & 71 & ND & $71^{* *}$ \\
\hline
\end{tabular}

Mean values were significantly different from those for counterpart animals given a soyabean meal diet: $* * P<0.01, * * * P<0 \cdot 001$.

(a) Isolated from a chicken crop.

(b) Isolated from the faecal flora of adult healthy humans.

ND: not determined.

GLUCOSINOLATES AND GLUCOSINOLATE DERIVATIVES: NEW CANDIDATES FOR PROTECTION AGAINST CHEMICAL CARCINOGENESIS

\section{EPIDEMIOLOGICAL DATA: CRUCIFEROUS VEGETABLES AND CANCER INCIDENCE IN HUMAN POPULATIONS}

Toxic effects of GSL and their derivatives in humans have seldom been described; in animals they are now less dramatic since new varieties of rape containing very low amounts of GSL have been bred. Nevertheless an ever increasing number of publications suggest a new potential of GSL-containing vegetables, namely that they may be serious candidates for protection against chemically induced cancer.

Different epidemiological studies (Graham et al. 1972, 1978; Haenzsel et al. 1980) seem to support the hypothesis that the consumption of cruciferous vegetables is associated with a lower risk of tumour formation in the human digestive tract (stomach, colon, rectum). Such observations led the (American) Committee on Diet, Nutrition and Cancer (1982) to suggest that the consumption of cruciferous vegetables "was associated with a reduction in the incidence of cancer at several sites in humans".

\section{EXPERIMENTAL DATA: CRUCIFEROUS VEGETABLES, GLUCOSINOLATES AND CHEMICAL CARCINOGENS IN ANIMAL MODELS}

The remarkable work carried out by Stoewsand and his team was a determining step in the experimental demonstration of the potentially beneficial effects of GSL consumption on chemically induced cancers. An initial experiment by these authors showed that giving rats a diet with $20 \%$ freeze-dried cauliflower reduced the toxic effects of aflatoxin B1 given 
orally (Stoewsand et al. 1978). This was subsequently supported by other studies by Boyd et al. (1982) using a diet with $25 \%$ freeze-dried cabbage, and by Salbe \& Bjeldanes (1989) using a diet with $25 \%$ chopped and freeze-dried Brussels sprouts. The latter authors showed that aflatoxin B1 binding to hepatic DNA was much decreased when rats had been given Brussels sprouts for 2 weeks prior to the intraperitoneal or intragastric administration of the toxin. Female rats were also significantly protected against the carcinogenic properties of 7,12-dimethylbenz( $a$ )anthracene administered by oral intubation when they received a feed containing $20 \%$ freeze-dried Brussels sprouts during the initiation period of carcinogenesis; in this 2-week experiment, the incidence of mammary tumours induced by 7,12-dimethylbenz $(a)$ anthracene dropped from $77 \%$ in the control animals to $13 \%$ in the animals consuming the cruciferous vegetable (Stoewsand et al. 1988). Other studies have highlighted the protective effect of GSL-rich diets against chemically induced tumours (Wattenberg \& Loub, 1978; Wattenberg et al. 1986).

However, these results showing the anticarcinogenic properties of cruciferous vegetables are counterbalanced by another series of experiments. Diets with $10 \%$ dried cabbage, for instance, have been shown to increase the incidence of pancreatic ductular carcinomas induced by $N$-nitroso-bis(2-oxopropyl)amine (Birt et al. 1987) in mice. A study carried out by Srisangnam et al. $(1980 a)$ is even more equivocal; the authors concluded that diets containing 10-20\% sliced dehydrated cabbage enhanced the tumorigenicity of 1,2dimethylhydrazine in mice whereas $40 \%$ cabbage in the feed has a protective effect. Although these results are very interesting, it is important to emphasize that in these cases 1,2-dimethylhydrazine and $N$-nitroso-bis(2-oxopropyl)amine were injected subcutaneously and that the greatest incidence of tumours was obtained with a high fat diet $(22 \%$; Birt et al. 1987).

The discrepancies observed between the findings can probably be explained partly by the tremendous variations in experimental design with respect to variables such as animal species, strain, sex, age, etc., the nature of the cruciferous vegetable and/or of the carcinogenic agent, the route of administration and/or the duration of the experiment. On the whole, these findings, albeit inconsistent, give definite evidence of the influence of cruciferous vegetables on chemical carcinogenesis.

In elucidating the anticarcinogenic properties of cruciferous vegetables, much of the work has focused on the effects of purified indolylGSL and derivatives. The main compound tested in these studies has been glucobrassicin and, more precisely, the derivatives obtained via its hydrolysis by plant myrosinase. When orally intubated into female rats before the administration of 7,12-dimethylbenz( $a$ )anthracene, I3C $(0 \cdot 10 \mathrm{mmol} / \mathrm{rat})$ and $3,3^{\prime}$-diindolylmethane $(0.05 \mathrm{mmol} / \mathrm{rat})$, but not IAN $(0 \cdot 10 \mathrm{mmol} / \mathrm{rat})$, significantly reduced the incidence of mammary tumours (Wattenberg \& Loub, 1978). Furthermore, mice given orally a $12 \mathrm{mg}$ dose of the parent compound, glucobrassicin, a few days or even a few hours $(4 \mathrm{~h})$ before oral administration of benzo( $a$ )pyrene (BaP), developed fewer forestomach and lung tumours (Wattenberg et al. 1986). In rats, I3C $(1 \mathrm{~g} / \mathrm{kg}$ diet) was shown to inhibit the hepatocarcinogenesis induced by diethylnitrosamine ( $40 \mathrm{mg} / 1$ drinking water) when it was administered concurrently with the carcinogen (Tanaka et al. 1990). Shertzer $(1983,1984)$ studied the change in binding to DNA of BaP or $N$-nitrosodimethylamine (NDMA) metabolites after mice were given I3C by gavage ( $163 \mathrm{mg} / \mathrm{kg}$ body weight); in both cases, there was evidence of a dramatic decrease in covalent binding. In contrast $13 \mathrm{C}$ proved unable to decrease the binding of aflatoxin $\mathrm{B} 1$ to hepatic DNA, whether it was administered via the intraperitoneal route or by gavage (Salbe \& Bjeldanes, 1989). Pence et al. (1986) even demonstrated that I3C incorporated into the diet at a level of $1 \mathrm{~g} / \mathrm{kg}$ dry matter enhanced 1,2-dimethylhydrazine induced tumorigenicity in rats; in this experiment, 1,2-dimethylhydrazine $(10 \mathrm{mg} / \mathrm{kg}$ body weight $)$ was injected 
intraperitoneally weekly for 16 weeks and the enhancing effect of $13 \mathrm{C}$ was significantly increased when the animals were given a high fat $(20 \%)$ diet.

Apart from sinigrin which was shown to exhibit a protective effect similar to that of I3C against diethylnitrosamine induced hepatocarcinogenesis (Tanaka et al. 1990), other GSL have received little or even no attention, so that a great deal of uncertainty remains about the extent to which GSL can impede the carcinogenic process. Nevertheless, as was observed with diets based on cruciferous vegetables, the effects of glucobrassicin or of some of its derivatives are not always protective. One of the most likely explanations for these inconsistent results, i.e. enhancement versus reduction of the incidence of cancers in experimental animal models, is that GSL and/or GSL derivatives may modify the endogenous system of xenobiotic metabolizing enzymes (XME).

\section{EXPERIMENTAL DATA: CRUCIFEROUS VEGETABLES, GLUCOSINOLATES AND XENOBIOTIC METABOLIZING ENZYMES}

\section{The xenobiotic metabolizing enzymes}

We do not explain in detail how the XME system, which is very complex, works, since excellent reviews have been published (Burke \& Orrenius, 1979; Kato, 1979; Caldwell, 1980). We give only a few examples which indicate the ways in which GSL can interfere with this biotransformation-detoxification system and help our understanding, at least in part, of their deleterious or protective effects.

The XME system is ubiquitous (skin, intestine, lungs, kidneys) with some exceptions, but is present mainly in the liver (Beaune, 1982, 1986). The reactions catalysed by the XME confer hydrophilic properties on endogenous compounds or molecules entering the organism that would otherwise be hard to eliminate due to their rather hydrophobic nature.

This system is usually described as having two phases, although a compound may be metabolized by either one or both phases (Jakoby, 1980). Phase one is represented by different enzymes such as flavin-containing monooxygenase, alcohol and aldehyde dehydrogenases, etc. The most widely studied enzymes belonging to phase I are undoubtedly the cytochrome $\mathrm{P} 450$ family $(E C 1.14 .14 .1)$, probably because they metabolize a tremendous number of substances (Jakoby, 1980). We do not go into details of the biochemistry of the reactions catalysed by P450; schematically, these microsomal monooxygenases incorporate one atom of molecular oxygen into an organic substrate while using reducing equivalents $\left(\mathrm{NADPH} / \mathrm{H}^{+}\right)$to reduce the remaining oxygen atom to water. Since the discovery of cytochrome P450 by G. R. Williams in B. Chance's laboratory in 1955 (Conney, 1982), it has become obvious that it plays a key role in the metabolism of many xenobiotic or endogenous substances. So far approximately twenty P450 isoenzymes in the liver of the rat have been described (Nebert et al. 1989). As far as human P450 are concerned, results are of course less straightforward, due to the wide differences that may exist between individuals (genetic background, xenobiotic exposure, dietary habits, etc.; Wrighton et al. 1986; Guengerich, 1989; Sesardic et al. 1990). Individual forms of P450 may exhibit different degrees of specificity toward multiple substrates, i.e. high $\mathbf{K}_{m}$ activities toward some substrates and low $\mathbf{K}_{m}$ activities toward others.

The reactive products released by phase I can be further metabolized by phase II enzymes. Phase II catalyses the conjugation of phase I intermediates with endogenous ligands such as amino acids, glucuronic acid, sulphate or glutathione. As for P450, phase II is represented by large families of isoenzymes with overlapping substrate specificities (Habig et al. 1974; Jakoby, 1978; Wishart, 1978; Bock et al. 1979). UDPglucuronosyltransferases (GT, EC 2.4.1.17) are microsomal enzymes that catalyse conjugation with 
UDPglucuronic acid (Bock et al. 1987; Burchell et al. 1987). It seems that glucuronidation is the most important form of conjugation. Three of the isoenzymes identified so far in the rat are involved in the glucuronidation of endogenous substrates such as bilirubin and steroid hormones. Hepatic glucuronides are usually excreted via the bile. Most of the compounds that can be glucuronidated can also be sulphated by sulphotransferases (EC 2.8.2.1 etc.). These enzymes are located in the cytosol and catalyse the formation of sulphate monoesters with $3^{\prime}$-phosphoadenosine-5'-phosphosulphate. The result of the competition for a substrate between sulphotransferases and GT is usually in favour of the former, at least when the substrate concentration is low. With the exception of one microsomal form, glutathione $S$-transferases (GST, EC 2.5.1.18) are cytosolic proteins which conjugate glutathione on the sulphur atom of cysteine to various electrophiles (Mannervik, 1985; Pickett \& Lu, 1989; Coles \& Ketterer, 1990). GST also play a key role in the transport of hormones to the cell nucleus. Epoxide hydrolases (EH, EC 3.3.2.3) are found in both the cytosol and the endoplasmic reticulum. Their action is important since they degrade reactive epoxides by the addition of water, thus generally leading to the less reactive diols. However EH can sometimes contribute to the genesis of potent carcinogens as seen with the transformation of $\mathrm{BaP}$ : the $\mathrm{EH}$ mediated 7,8-dihydrodiol metabolite is less reactive than the parent molecule but cytochrome P450 can convert it into an extremely reactive epoxide responsible for the well-known mutagenic and carcinogenic properties of BaP. As with all other enzymes so far described, EH is also involved in the biotransformation of endogenous intermediates such as oestrogen and androgen epoxides (Timms et al. 1987).

Depending on their molecular weight, structure and polarity, conjugated metabolites are eliminated via urine or bile. Before urinary excretion, glutathione conjugates are further metabolized into mercapturic acids. Metabolites excreted via the biliary route may be partly hydrolysed by intestinal microflora and reabsorbed. This last transformation constitutes the first step of an enterohepatic cycle (Rowland, 1988).

Although XME is usually considered a detoxification system, such is not always the case. A lot of examples are known where it enhances or generates toxicity (carcinogenicity). On the whole it seems that the role of $\mathrm{P} 450$ in the toxification $v$. detoxification balance is far more ambiguous than that of phase II transferases. It is usually accepted, with some exceptions such as morphine-6-glucuronide (Caldwell, 1979), that an increase in the specific activities of transferases enhances detoxification. The XME system is very versatile and many factors may modulate its capacity. Apart from genetic characteristics (species, gender, individual), inducers may specifically enhance some of its activities, thus orienting its detoxification or toxification potential (Conney, 1982; Guengerich et al. 1982; Ullrich \& Bock, 1984). Consequently, the induction of an isoform of $\mathrm{P} 450$ by a xenobiotic can have grave consequences for the fate of another xenobiotic, particularly if the latter is activated into a reactive toxic or carcinogenic metabolite by the isoform.

\section{The effects of cruciferous vegetables on the XME system}

A lot of work has been done since epidemiological and experimental findings first supported the idea of a protective role of GSL-rich diets against cancer. Most researchers have tried to elucidate the mechanism by which GSL and/or their derivatives could alter the XME system, both in the liver and the intestine.

Historically, the first work on that topic was performed by Wattenberg (1971) who showed that $\mathrm{BaP}$ hydroxylation in the rat intestine was very much enhanced when the animals were given a cabbage based diet. This study was then extended to other cruciferous vegetables and other activities of the phase I XME. McDanell et al. (1989) described the enhancement of ethoxyresorufin deethylation activity in the small intestine (5-fold), in the 
colon (4-fold) and in the liver ( 2.5 -fold) of rats given a diet with $25 \%$ freeze-dried Brussels sprouts for $6 \mathrm{~d}$. Similarly, feeding rats for 2 weeks on a diet containing $25 \%$ chopped and freeze-dried Brussels sprouts led to the induction (2-fold) of intestinal aryl hydrocarbon hydroxylase and ethoxycoumarin $O$-deethylase activities (Salbe \& Bjeldanes, 1989). However no induction was seen in the liver, as already reported by Hendrich \& Bjeldanes (1983) in mice fed on diets containing $20 \%$ chopped and freeze-dried cabbage or Brussels sprouts. A single meal of a GSL-containing food ( $25 \%$ dried cabbage) is not enough to modify the ethoxyresorufin deethylation activity in the liver and colon but it succeeds in inducing a temporary enhancement of this activity in the small intestine, the peak occurring 4-6 h post ingestion (McDanell et al. 1989). In our laboratory, monoclonal antibodies were used to investigate the influence of a diet with $39 \%$ rapeseed meal on the isoenzyme pattern of P450 in the liver of male rats. After 4 weeks, an overall reduction in the total P450 $(-25 \%)$ occurred resulting from a $66 \%$ decrease of the $2 \mathrm{C} 11$ (male constitutive) form whereas the 1A1/1A2 (polycyclic hydrocarbon inducible) form was enhanced by $61 \%$; the 2B1/B2 (phenobarbital inducible), 2E (ethanol inducible) and 3A (steroid inducible) forms also measured were not significantly modified (Nugon-Baudon et al. 1991).

Concerning phase II enzymes, giving rats for $10 \mathrm{~d}$ a diet containing $25 \%$ freeze-dried Brussels sprouts was shown to induce hepatic and intestinal GST and intestinal EH (Bradfield \& Bjeldanes, 1984). Such phenomena were also observed by Aspry \& Bjeldanes (1983) using diets containing 10-25\% chopped freeze-dried broccoli. We have reproduced the induction of hepatic GST ( $2 \cdot 5$-fold) in rats given a diet with $39 \%$ rapeseed meal for 4 weeks and extended the investigations to hepatic GT; the activity of this last conjugative enzyme was dramatically enhanced (4-fold; Nugon-Baudon et al. 1990a). As far as hepatic $\mathrm{EH}$ is concerned, a slight stimulation (1.4-fold) was observed in mice fed for $10 \mathrm{~d}$ on a diet containing $20 \%$ chopped and freeze-dried Brussels sprouts but it did not occur when Brussels sprouts were replaced with cabbage (Hendrich \& Bjeldanes, 1983).

The effects of various cruciferous vegetables on the phase I system seem to vary. Discrepancies between the experimental designs could be held responsible; indeed, Miller \& Stoewsand (1983) have clearly shown that the phase I system of different strains of rats responded in different ways to a cabbage-containing diet. In contrast, results obtained on phase II are less divergent and there is now strong evidence of an overall induction of transferases in the intestine as well as the liver, whatever the experimental design.

It is now well known that the content and pattern of intact GSL and GSL derivatives are very much affected by the processing operations undergone by cruciferous vegetables before consumption. As cooking is one of the most usual treatments the question is, do cooked cruciferous vegetables modify the intestinal and/or hepatic XME, and if so how? Very few studies have been published on this issue. Recently, Wortelboer et al. (1992) have addressed the topic, using Brussels sprouts cooked for $20 \mathrm{~min}$ in unsalted water; consequently, the total GSL concentration dropped from 7.3 to $4.9 \mathrm{mmol} / \mathrm{kg}$ dry matter. Rats were given semi-synthetic diets containing either $0,2 \cdot 5,5$ or $20 \%$ cooked Brussels sprouts on a dry matter basis. Animals of each dietary group were killed after 2, 7, 14 or $28 \mathrm{~d}$ in order to assess the effects of the different levels of Brussels sprouts on hepatic and intestinal phase I and phase II enzymes. GST activity was induced throughout the experiment, in the intestine only by the $20 \%$ diet, and in the liver by diets containing at least $5 \%$ Brussels sprouts. From $2 \mathrm{~d}$ treatment onwards, the $20 \%$ diet also induced hepatic $\mathrm{NAD}(\mathrm{P}) \mathrm{H}$ quinone reductase $(E C$ 1.6.99.2) and GT1 activities but it decreased hepatic GT2 activity. As far as P450 isoenzymes are concerned, polycyclic hydrocarbon inducible forms, i.e. $1 \mathrm{~A} 2$ in the liver and $2 \mathrm{~B} 1 / \mathrm{B} 2$ in the small intestine, were induced in a dose related manner by all diets containing Brussels sprouts throughout the experiment. Apart from the immunochemical detection of apoproteins, the authors have used marker substrates to try 
to correlate Western-blot results and enzyme activities. Some were possible: enhanced ethoxyresorufin deethylation activity in the liver is correlated with the induction of 1A2, and increased $16 \alpha$ - and $16 \beta$-hydroxylation of testosterone by intestinal microsomes is correlated with the induction of the intestinal 2B isoenzyme. These results are quite important, since they show that cruciferous vegetables processed in the way that they usually are in a human diet may alter very significantly the XME system.

\section{The effects of glucosinolates and glucosinolate derivatives on the XME system}

Consistent with the work performed on the anticarcinogenic properties of pure GSL and GSL derivatives, most studies investigating the GSL linked alterations of the XME have strongly focused on indolylGSL and their enzymic derivatives.

Of four pure GSL, sinigrin, progoitrin, glucotropaeolin and glucobrassicin, only the last compound has been shown to induce phase I enzymes significantly, at least in the rat small intestine (McDanell et al. 1989). Loub et al. (1975) repeated the original work of Wattenberg (1971) on BaP hydroxylation, using pure I3C, 3,3'-diindolylmethane, IAN and ascorbigen as potential XME inducers. Given to rats by gavage a few hours before they were killed, these glucobrassicin derivatives induced $\mathrm{BaP}$ hydroxylation in the liver and the small intestine. $13 \mathrm{C}$ was tremendously active : a single $0.1 \mathrm{mmol}$ dose induced 56- and 31 -fold enhancements of BaP hydroxylation in the liver and small intestine respectively. Related studies, in which three glucobrassicin derivatives were given to rats twice daily for $3 \mathrm{~d}$, corroborate this result (Pantuck et al. 1976); 3,3'-diindolylmethane $(175 \mathrm{mg} / \mathrm{kg}$ body weight), IAN (95 mg/ $\mathrm{kg})$ and, to an even more important extent, I3C (100 mg/ $\mathrm{kg})$ each increased the intestinal metabolism of phenacetin, 7-ethoxycoumarin, hexobarbitone and $\mathrm{BaP}$. I3C can modify the metabolism of other chemicals as well. In rainbow trout, dietary I3C ( $2 \mathrm{~g} / \mathrm{kg}$ diet on a dry matter basis) is involved in substantial changes in the distribution, metabolism and elimination of aflatoxin B1, leading to significantly reduced hepatic DNA damage (Goeger et al. 1986). In liver microsomes prepared from rats fed for 2 weeks on an I3C-containing diet ( $30 \mathrm{mmol} / \mathrm{kg}$ on a dry matter basis) $\alpha$-hydroxylation of NDMA and 4-(methylnitrosamino)-1-(3-pyridyl)-1-butanone (NNK), which are environmentally prevalent nitrosamines, is enhanced; in this case, the inducing effect of $13 \mathrm{C}$ is particularly harmful since it enhances the release of reactive intermediates binding to DNA (Chung $e t$ al. 1985). Bradfield \& Bjeldanes (1984) reported that a dose of $I 3 C$ as low as $50 \mathrm{mg} / \mathrm{kg}$ synthetic diet, given to rats for $10 \mathrm{~d}$, led to a 6-fold increase of BaP hydroxylation activity in the small intestine. Gradually increasing the dose up to $500 \mathrm{mg} / \mathrm{kg}$ led to a positively correlated level of induction. The same effect was seen with intestinal ethoxycoumarin $O$ deethylase. However no effect on the hepatic counterparts of these activities could be seen, whatever the diet and the $\mathrm{I3C}$ concentration, though a slight increase in total P450 concentration occurred when animals were given the $500 \mathrm{mg} / \mathrm{kg} \mathrm{I3C} \mathrm{diet.} \mathrm{Shertzer} \mathrm{(1982)}$ also found contrasting results when he administered comparable doses of IAN or I3C to mice, rats and rabbits, orally or via the intraperitoneal route, daily for $10 \mathrm{~d}$ : IAN had no effect on either hepatic cytochrome $\mathrm{P} 450$ or BaP hydroxylation activity in any of the three animal species; with I3C, a 2-fold induction of hepatic P450 and BaP hydroxylation could be seen in the liver of mice and rats but not rabbits. On the whole, the induction level was much weaker than those reported elsewhere, especially considering that the administration of the GSL derivatives lasted a rather long time. The controversy increased with the findings of Babish \& Stoewsand (1978); using rats given dietary levels of I3C ranging from 50 to $7500 \mathrm{mg} / \mathrm{kg}$ diet for 3 weeks, these authors observed a significant induction of intestinal BaP hydroxylation activity only at a dose that would correspond to a daily intake of $1.5 \mathrm{~g} / \mathrm{kg}$ body weight, which is totally unrealistic for a human diet! Therefore the authors concluded that $\mathrm{I} 3 \mathrm{C}$ is not the major inducer of phase I activities. 
Once again, it is regrettable that so few studies have been conducted on other GSL or GSL derivatives. Nevertheless, among them, goitrin has received particular attention. According to Chang \& Bjeldanes (1985), goitrin given to rats does not alter the ethoxycoumarin $O$-deethylase activity, either in the liver or in the small intestine, even at the lowest dose tested $(40 \mathrm{mg} / \mathrm{kg}$ diet for $14 \mathrm{~d})$. Recently Ozierenski et al. (1993) concluded that dietary goitrin is able to modify phase I activities in the rat liver, though in a contrasting way; whereas no significant modification of the overall P450 concentration occurred, aminopyrine $N$-demethylation was reduced and aniline $p$-hydroxylation was enhanced in a dose dependent manner. Ozierenski et al. (1993) have extended their investigations to a series of isothiocyanate derivatives and to 1-cyano-3-butene, the nitrile derived from gluconapin; on the whole, the overall concentration of P450 is significantly reduced and is accompanied by a dose related decrease of several P450 dependent activities such as aminopyrine $N$-demethylation, aniline $p$-hydroxylation and $p$-nitroanisole $O$ demethylation. Such results support our own findings concerning the heterogeneous alterations of the isoenzyme profile of P450 in the liver induced by rapeseed meal (NugonBaudon et al. 1991). In vivo consequences of the alterations of P450 activities by isothiocyanates have been investigated by Chung et al. (1985). These authors showed that isothiocyanates such as allyl-, benzyl- and phenylethylisothiocyanate, derived from sinigrin, glucotropaeolin and gluconasturtiin respectively, were good inhibitors of NDMA and NNK $\alpha$-hydroxylation in liver microsomes prepared from rats fed for 2 weeks on a diet containing one of these compounds $(3 \mathrm{mmol} / \mathrm{kg}$ dry matter); similar treatment with sinigrin also caused a significant decrease in the $\alpha$-hydroxylation of these nitrosamines. In view of their promising inhibitory activities, the effects of dietary phenylethylisothiocyanate and sinigrin on the in vivo methylation of DNA by NDMA $(25 \mathrm{mg} / \mathrm{kg}$ body weight by intraperitoneal injection) and NNK ( $85 \mathrm{mg} / \mathrm{kg}$ body weight by intravenous injection) were evaluated. The results were parallel to those obtained in the in vitro assays, suggesting that these compounds might be potent inhibitors of NDMA and NNK carcinogenesis.

Compared with phase I activities, the influence of GSL and GSL derivatives on phase II XME has been less fully investigated. Sparnins et al. (1982) showed that a semi-purified diet containing $6 \mathrm{~g} / \mathrm{kg} \mathrm{I3C}$ induced intestinal and hepatic GST (3-fold) after a $10 \mathrm{~d}$ trial in mice. A comparable result was reported later on hepatic EH (Cha et al. 1985). In both studies, the levels of $13 \mathrm{C}$ were very high and not to be found in a human diet. Using a diet containing $0.5 \mathrm{~g} / \mathrm{kg} \mathrm{I3C}$, Wortelboer (1991) found a slight induction of liver and intestinal GST after $2 \mathrm{~d}$ and an induction of GT after $7 \mathrm{~d}$ in the rat. Nevertheless, other authors have published results that tend to show that no induction of intestinal or hepatic GST or EH activities by I3C is possible at normal dietary levels (Bradfield \& Bjeldanes, 1984; Salbe \& Bjeldanes, 1989). Although a diet with Brussels sprouts given to rats for $10 \mathrm{~d}$ induces both GST and EH in the liver as well as in the small intestine, synthetic diets containing $50-500 \mathrm{mg} / \mathrm{kg} \mathrm{I3C}$ do not alter these activities at all (Bradfield \& Bjeldanes, 1984).

There is now firm evidence that glucobrassicin and its derivatives cannot exclusively account for the phase II alterations observed when feeding crucifer-containing diets, far from it. This point has prompted several groups to look for effects of other GSL and GSL derivatives. One of the inducing molecules for phase II enzymes was identified as goitrin (Chang \& Bjeldanes, 1985); when given to rats $(40 \mathrm{mg} / \mathrm{kg}$ diet) for $14 \mathrm{~d}$, this progoitrin derivative was able to increase significantly hepatic GST and EH activities. Ozierenski $e t$ al. (1993) addressed the same point, comparing the effects of goitrin and the gluconapin derivatives, 1-cyano-3-butene and butenyl isothiocyanate, and various isothiocyanates on GST in rat liver. All compounds tested, other than 1-cyano-3-butene, caused an increase in GST activity. In another very recent study, Zhang et al. (1992) applied a glucoiberin derivative, 1-isothiocyanato-( $3 R$ )-(methylsulphinyl) propane (IMSP), and a glucoraphanin 
derivative, 1-isothiocyanato-(4R)-(methylsulphinyl) butane, to a Hepa 1c1c7 murine hepatoma cell culture and found that both these derivatives were potent inducers of GST and NAD(P)H quinone reductase. These results were of extreme importance and deserved to be confirmed and qualified in vivo, which was done by Kore et al. in 1993. IMSP doses of 1,10 and $100 \mu \mathrm{mol} / \mathrm{kg}$ body weight were given by gavage to rats once daily for $7 \mathrm{~d}$; the lowest dose was, according to the authors, comparable to what an average western diet would contain. No alterations, whatever the dose, could be seen in hepatic levels of cytochrome $\mathrm{P} 450$, ethoxycoumarin $O$-deethylase or aminopyrine $N$-demethylase activities or in hepatic quinone reductase, GST and GT. However an important induction of intestinal quinone reductase (8-fold) and a moderate induction of intestinal GST (2-fold) occurred, but only at the highest dose of IMSP. Thus it was concluded that the IMSP content occurring in an average human diet may have no significant influence on either phase I or phase II enzymes.

All these findings definitely show that the XME alterations mediated by cruciferous vegetables involve many kinds of GSL derivatives. The numerous dose related studies reported here highlight the fact that one must be extremely cautious in extrapolating alterations observed under experimental conditions to real nutritional conditions; it seems that some molecules, albeit undeniably active towards XME, are eventually not relevant from a nutritional point of view and should rather be considered as candidates for pharmacological investigation.

\section{CONCLUSIONS AND PENDING TOPICS}

One of the major points which remains to be addressed is of course how far it is possible to extrapolate to humans results established in laboratory rodents.

Only a few studies have been performed so far in humans, for obvious reasons. Nevertheless the pharmacological fates of some drugs which are known to be metabolized by the XME system have been examined by Pantuck and coworkers in volunteers consuming cruciferous vegetables. The metabolism of phenacetin and antipyrine and the glucuronidation of paracetamol are enhanced by the consumption of Brussels sprouts, cabbage and other cruciferous-containing diets (Pantuck et al. 1979, 1984). In a review on indolylGSL, McDanell et al. (1988) support the idea that GSL derivatives are likely to be as active on the XME system of humans as they are in laboratory animals.

Among the most striking points, when looking at the findings reported in the present review, are the conflicting results which appear to arise from the diversity of amounts of cruciferous vegetables and GSL or GSL derivatives incorporated in the rodent diets. Furthermore, where cruciferous vegetables have been used, the reader has sometimes been poorly informed on the GSL content resulting from the process undergone by the vegetable before its incorporation into the diet. Since cruciferous vegetables are usually eaten after treatments such as mashing, fermenting, cooking, etc., reports on the effects of such treatments on the GSL related XME alterations would be a crucial matter to develop in order to extend data provided by the original works of McDanell et al. (1987), Wortelboer (1991) and Wortelboer et al. (1992).

All the studies reported here deal with the impact of GSL on environmental procarcinogens and/or carcinogens biotransformed via the XME system. Very few studies have investigated the extent to which GSL may alter steroid metabolism, though this point could be important for hormone dependent cancers in the human. Michnovicz \& Bradlow (1991) have shown that in twelve healthy men and women ingestion of 6-7 mg/day of I3C for $7 \mathrm{~d}$ increased the 2-hydroxylation of oestradiol by about $50 \%$, thus enhancing the urinary excretion of 2-hydroxyoestrone relative to the excretion of oestriol. In a 
Table 7. Effects of a diet with rapeseed meal on three hepatic xenobiotic metabolizing enzymes in germ free and conventional rats

(Results are expressed as \% of the mean values obtained with counterpart rats given a diet with soyabean meal)

\begin{tabular}{lcc}
\hline Bacterial status... & $\begin{array}{c}\text { Conventional } \\
\text { Rugon-Baudon } \text { et al. } \\
\text { Reference... }\end{array}$ & Germ free \\
Duration of trial & 4 & 3 \\
(weeks)... & 11 & 8 \\
No. of animals ... & $75^{* *}$ & 80 \\
Cytochrome P450 & al. (1993b) \\
Glutathione- $S$-transferase & $236^{* *}$ & 105 \\
UDP-glucuronosyltransferase & $372^{* *}$ & 102 \\
\hline \hline
\end{tabular}

Mean values were significantly different from those for counterpart animals given a soyabean meal diet: ** $P<0 \cdot 01$.

spontaneous mammary tumour mouse model, tumour incidence and multiplicity were significantly reduced after mice had received a diet containing 500 or $2000 \mathrm{mg} / \mathrm{kg} \mathrm{I3C}$ for 8 months; in this model, I3C increased the level of oestradiol 2-hydroxylation up to 5-fold. The authors concluded that the protective effect may have resulted from increased 2hydroxylation and inactivation of endogenous oestrogens (Bradlow et al. 1991). This could be a clue that GSL influence on carcinogenesis might result from alterations of the XME mediated biotransformation of exogenous compounds as well as endogenous molecules.

Finally, all pure GSL derivatives examined so far, in cell cultures and in vivo, originate from hydrolysis by plant myrosinase. Since GSL derivatives produced by myrosinase-like activities of the intestinal microflora are able to induce toxic effects, one wonders whether they are able to induce XME alterations as well. A first answer arises from experiments performed in our laboratory using conventional and germ free rats: the decrease in total P450 concentration as well as the induction of GST and GT observed in the liver of conventional rats given a GSL-rich but myrosinase free diet cannot be reproduced in germ free animals (Table 7; Nugon-Baudon et al. 1990 a; Rabot et al. 1993 b). These findings indicate that, should myrosinase be absent from the diet, bacterial metabolism would substitute for it and produce GSL derivatives capable of altering the XME system. Primary GSL derivatives produced by plant myrosinase or by the microflora may also undergo further transformations in the body. Whether or not these putative second metabolic steps are mediated by the intestinal microflora, one may think that the active GSL metabolites may not be exclusively the aglucones released by the plant myrosinase or the primary metabolites released by the microflora. We have been able to offer some support for this hypothesis (Nugon-Baudon et al. 1990a) by showing that a pretreatment with phenobarbital led to enhancement of several GSL linked toxic effects in conventional rats.

On the whole there is still a tremendous and varied scope for further research in the field of relationships between glucosinolates and cancer. The numerous studies already performed and the hypotheses already suggested demonstrate the challenge to the imagination and ingenuity of nutritionists, pharmacologists, chemists and bacteriologists posed by the puzzle.

\section{REFERENCES}

Adams, H., Vaughan, J. G. \& Fenwick, G. R. (1989). The use of glucosinolates for cultivar identification in swede, Brassica napus L var napobrassica (L) Peterm. Journal of the Science of Food and Agriculture 46, 319-324. 
Akiba, Y. \& Matsumoto, T. (1976). Antithyroid activity of goitrin in chicks. Poultry Science 55, 716-719.

Aspry, K. E. \& Bjeldanes, L. F. (1983). Effects of dietary broccoli and butylated hydroxyanisole on liver-mediated metabolism of benzo[a]pyrene. Food and Chemical Toxicology 21, 133-142.

Astwood, E. B., Greer, M. A. \& Ettlinger, M. G. (1949). 1-5-vinyl-2-thiooxazolidone, an antithyroid compound from yellow turnip and from brassica seeds. Journal of Biological Chemistry 181, 121-130.

Austin, F. L., Gent, C. A. \& Wolff, I. A. (1968). Degradation of natural thioglucosides with ferrous salts. Journal of Agricultural and Food Chemisty 16, 752-755.

Babish, J. G. \& Stoewsand, G. S. (1978). Effect of dietary indole-3-carbinol on the induction of the mixedfunction oxidases of rat tissue. Food and Cosmetics Toxicology 16, 151-155.

Beaune, P. (1982). Les cytochromes P450 des microsomes de foie humain: activités monooxygénasiques et purification partielle (Microsomal P450 Cytochromes in Human Liver: Monoxygenase Activities and Partial Purification), PhD thesis, University of Paris 6, $139 \mathrm{pp}$.

Beaune, P. (1986). [Liver P450 cytochromes in humans.] Médecine/Sciences 2, 358-363.

Bell, J. M. (1984). Nutrients and toxicants in rapeseed meal: a review. Journal of Animal Science 58, 996-1010.

Bell, J. M., Benjamin, B. R. \& Giovannetti, P. M. (1972). Histopathology of thyroids and livers of rats and mice fed diets containing Brassica glucosinolates. Canadian Journal of Animal Science 52, 395-406.

Benns, G. B., Hall, J. W. \& Beare-Rogers, J. L. (1978). Intake of brassicaceous vegetables in Canada. Canadian Journal of Public Health 69, 64-66.

Bille, N., Eggum, B. O., Jacobsen, I., Olsen, O. \& Sorensen, H. (1983). Antinutritional and toxic effects in rats of individual glucosinolates ( \pm myrosinases) added to a standard diet. 1. Effects on protein utilization and organ weights. Zeitschrift für Tierphysiolgie, Tierernährung und Futtermittelkunde 49, 195-210.

Birt, D. F., Pelling, J. C., Pour, P. M., Tibbels, M. G., Schweickert, L. \& Bresnick, E. (1987). Enhanced pancreatic and skin tumorigenesis in cabbage fed hamsters and mice. Carcinogenesis 8, 913-917.

Bjerg, B. \& Sørensen, H. (1987). Quantitative analysis of glucosinolates in oilseed rape based on HPLC of desulfoglucosinolates and HPLC of intact glucosinolates. World Crops: Production, Utilization and Description $13,125-150$.

Bock, K. W., Josting, D., Lilienblum, W. \& Pfeil, H. (1979). Purification of rat-liver microsomal UDPglucuronyltransferase: separation of two enzyme forms inducible by 3-methylcholanthrene or phenobarbital. European Journal of Biochemistry 98, 19-26.

Bock, K. W., Lilienblum, W., Fischer, G., Schirmer, G. \& Bock-Hennig, B. S. (1987). Induction and inhibition of conjugating enzymes with emphasis on UDP-glucuronyltransferases. Pharmacology and Therapeutics 33, 23-27.

Booth, E. J., Walker, K. C. \& Griffiths, D. W. (1990). Effect of harvest date and pod position on glucosinolates in oilseed rape (Brassica napus). Journal of the Science of Food and Agriculture 53, 43-61.

Bourdon, D., Perez, J.-M. \& Baudet, J.-J. (1981). [New types of rapeseed meal fed to growing-finishing pigs: influence of glucosinolates and dehulling.] Journées de la Recherche Porcine en France 13, 163-178.

Boyd, J. N., Babish, J. G. \& Stoewsand, G. S. (1982). Modification by beet and cabbage diets of aflatoxin $\mathbf{B}_{1-}$ induced rat plasma $\alpha$-foetoprotein elevation, hepatic tumorogenesis, and mutagenicity of urine. Food and Chemical Toxicology 20, 47-52.

Bradfield, C. A. \& Bjeldanes, L. F. (1984). Effect of dietary indole-3-carbinol on intestinal and hepatic monooxygenase, glutathione $S$-transferase and epoxide hydrolyase activities in the rat. Food and Chemical Toxicology 22, 977-982.

Bradfield, C. A. \& Bjeldanes, L. F. (1987). High-performance liquid chromatographic analysis of anticarcinogenic indoles in Brassica oleracea. Journal of Agricultural and Food Chemistry 35, 46-49.

Bradlow, H. L., Michnovicz, J. J., Telang, N. T. \& Osborne, M. P. (1991). Effects of dietary indole-3-carbinol on estradiol metabolism and spontaneous mammary tumors in mice. Carcinogenesis 12, 1571-1574.

Buchwaldt, L., Larsen, L. M., Plöger, A. \& Sørensen, H. (1986). Fast polymer liquid chromatography isolation and characterization of plant myrosinase, $\beta$-thioglucoside glucohydrolase, isoenzymes. Journal of Chromatography 363, 71-80.

Burchell, B., Jackson, M. R., Coughtrie, M. W. H., Harding, D., Wilson, S. \& Bend, J. R. (1987). Molecular characterization of hepatic UDP-glucuronyl transferases. In Drug Metabolism: From Molecules to Man, pp. 40-54 [D. Benford, J. W. Bridges and G. G. Gibson, editors]. London: Taylor and Francis.

Burke, M. D. \& Orrenius, S. (1979). Isolation and comparison of endoplasmic reticulum membranes and their mixed function oxidase activities from mammalian extrahepatic tissues. Pharmacology and Therapeutics 7 , 549-599.

Butler, E. J., Pearson, A. W. \& Fenwick, G. R. (1982). Problems which limit the use of rapeseed meal as a protein source in poultry diets. Journal of the Science of Food and Agriculture 33, 866-875.

Caldwell, J. (1979). Minireview. The significance of phase II (conjugation) reactions in drug disposition and toxicity. Life Sciences 24, 571-578.

Caldwell, J. (1980). Conjugation reactions. In Concepts in Drug Metabolism, vol. 10(A), pp. $211-217$ [P. Jenner and B. Testa, editors]. Basel: Decker.

Carlson, D. G., Daxenbichler, M. E., VanEtten, C. H., Hill, C. B. \& Williams, P. H. (1985). Glucosinolates in radish cultivars. Journal of the American Society for Horticultural Science 110, 634-638.

Carlson, D. G., Daxenbichler, M. E., VanEtten, C. H., Kwolek, W. F. \& Williams, P. H. (1987). Glucosinolates 
in crucifer vegetables: broccoli, Brussels sprouts, cauliflower, collards, kale, mustard greens, and kohlrabi. Journal of the American Society for Horticultural Science 112, 173-178.

Carlson, D. G., Daxenbichler, M. E., VanEtten, C. H., Tookey, H. L. \& Williams, P. H. (1981). Glucosinolates in crucifer vegetables: turnips and rutabagas. Journal of Agricultural and Food Chemistry 29, 1235-1239.

Cha, Y. N., Thompson, D. C., Heine, H. S. \& Chung, J. H. (1985). Differential effects of indole, indole-3-carbinol and benzofuran on several microsomal and cytosolic enzyme activities in mouse liver. Korean Journal of Pharmacology (Taehan Yakrihak Chapchi) 21, 1-11.

Chang, Y. \& Bjeldanes, L. F. (1985). Effect of dietary $R$-goitrin on hepatic and intestinal glutathione $S$ transferase, microsomal epoxide hydratase and ethoxycoumarin $O$-deethylase activities in the rat. Food and Chemical Toxicology 23, 905-909.

Chung, F.-L., Wang, M. \& Hecht, S. S. (1985). Effects of dietary indoles and isothiocyanates on $N$ nitrosodimethylamine and 4-(methylnitrosamino)-1-(3-pyridyl)-1-butanone $\alpha$-hydroxylation and DNA methylation in rat liver. Carcinogenesis 6, 539-543.

Coles, B. \& Ketterer, B. (1990). The role of glutathione and glutathione transferases in chemical carcinogenesis. CRC Critical Reviews in Biochemistry and Molecular Biology 25, 47-70.

Committee on Diet, Nutrition and Cancer, National Research Council (1982). Diet, Nutrition and Cancer. Washington DC: National Academy Press.

Conney, A. H. (1982). Induction of microsomal enzymes by foreign chemicals and carcinogenesis by polycyclic aromatic hydrocarbons: G. H. A. Clowes Memorial Lecture. Cancer Research 42, 4875 4917.

Daxenbichler, M. E., VanEtten, C. H. \& Williams, P. H. (1979). Glucosinolates and derived products in cruciferous vegetables. Analysis of 14 varieties of Chinese cabbage. Journal of Agricultural and Food Chemistry 27, 34-37.

de Vos, R. H. \& Blijleven, W. G. H. (1988). The effect of processing conditions on glucosinolates in cruciferous vegetables. Zeitschrift für Lebensmittel-Untersuchung und -Forschung 187, 525-529.

Duncan, A. J. \& Milne, J. A. (1989). Glucosinolates. In Anti-nutritional Factors, Potentially Toxic Substances in Plants (Aspects of Applied Biology 19), pp. 75-92.

Duncan, A. J. \& Milne, J. A. (1992). Rumen microbial degradation of allyl cyanide as a possible explanation for the tolerance of sheep to brassica-derived glucosinolates. Journal of the Science of Food and Agriculture 58, $15-19$.

Elfving, S. (1980). Studies in the naturally occurring goitrogen 5-vinyl-2-thiooxazolidone. Annals of Clinical Research 12, Suppl. 28, 7-47.

Etienne, M. \& Dourmad, J.-Y. (1987). [Effects of high or low-glucosinolate varieties of rapeseed meal on reproduction in sow.] Journées de la Recherche Porcine en France 19, 231-238.

Ettlinger, M. G., Dateo, G. P., Harrison, B. W., Mabry, T. J. \& Thompson, C. P. (1961). Vitamin C as a coenzyme: the hydrolysis of mustard oil glucosides. Proceedings of the National Academy of Sciences, USA 47, $1875-1880$.

Ettlinger, M. G. \& Lundeen, A. J. (1956). The structures of sinigrin and sinalbin; an enzymatic rearrangement. Journal of the American Chemical Society 78, 4172-4173.

Fenwick, G. R., Butler, E. J. \& Brewster, M. A. (1983). Are brassica vegetables aggravating factors in trimethylaminuria (fish odour syndrome)? Lancet ii, 916.

Fenwick, G. R., Heaney, R. K., Hanley, A. B. \& Spinks, E. A. (1986). Glucosinolates in food plants. In Food Research Institute, Norwich, Annual Report.

Fenwick, G. R., Heaney, R. K. \& Mullin, W. J. (1982). Glucosinolates and their breakdown products in food and food plants. CRC Critical Reviews in Food Science and Nutrition 18, 123-201.

Gil, V. \& MacLeod, A. J. (1980). The effects of $\mathrm{pH}$ on glucosinolate degradation by a thioglucoside glucohydrolase preparation. Phytochemistry 19, 2547-2551.

Goeger, D. E., Shelton, D. W., Hendricks, J. D. \& Bailey, G. S. (1986). Mechanisms of anti-carcinogenesis by indole-3-carbinol: effect on the distribution and metabolism of aflatoxin $\mathrm{B}_{1}$ in rainbow trout. Carcinogenesis 7 , 2025-2031.

Gould, D. H., Fettman, M. J. Daxenbichler, M. E. \& Bartuska, B. M. (1985). Functional and structural alterations of the rat kidney induced by the naturally occurring organonitrile, $2 S$-1-cyano-2-hydroxy-3,4epithiobutane. Toxicology and Applied Pharmacology 78, 190-201.

Graham, S., Dayal, H., Swanson, M., Mittelman, A. \& Wilkinson, G. (1978). Diet in the epidemiology of cancer of the colon and rectum. Journal of the National Cancer Institute 61, 709-714.

Graham, S., Schotz, W. \& Martino, P. (1972). Alimentary factors in the epidemiology of gastric cancer. Cancer 30, 927-938.

Greer, M. A. (1962). The natural occurrence of goitrogenic agents. Recent Progress in Hormone Research 18, $187-219$.

Greer, M. A. \& Astwood, E. B. (1948). The antithyroid effect of certain foods in man as determined with radioactive iodine. Endocrinology $43,105-119$.

Greer, M. A. \& Deeney, J. M. (1959). Antithyroid activity elicited by the ingestion of pure progoitrin, a naturally occurring thioglycoside of the turnip family. Journal of Clinical Investigation 38, 1465-1474.

Guengerich, F. P. (1989). Polymorphism of cytochrome P-450 in humans. Trends in Pharmacological Sciences 10, 107-109. 
Guengerich, F. P., Dannan, G. A., Wright, S. T., Martin, M. V. \& Kaminsky, L. S. (1982). Purification and characterization of liver microsomal cytochromes P-450: electrophoretic, spectral, catalytic, and immunochemical properties and inducibility of eight isozymes isolated from rats treated with phenobarbital or $\beta$ naphthoflavone. Biochemistry 21, 6019-6030.

Habig, W. H., Pabst, M. J. \& Jakoby, W. B. (1974). Glutathione-S-Transferases: the first enzymatic step in mercapturic acid formation. Journal of Biological Chemistry 249, 7130-7139.

Haenszel, W., Locke, F. B. \& Segi, M. (1980). A case-control study of large bowel cancer in Japan. Journal of the National Cancer Institute 64, 17-22.

Heaney, R. K. \& Fenwick, G. R. (1980a). Glucosinolates in Brassica vegetables. Analysis of 22 varieties of Brussels sprout (Brassica oleracea var, gemmifera). Journal of the Science of Food and Agriculture 31, 785-793.

Heaney, R. K. \& Fenwick, G. R. (1980 b). The glucosinolate content of Brassica vegetables. A chemotaxonomic approach to cultivar identification. Journal of the Science of Food and Agriculture 31, 794-801.

Hendrich, S. \& Bjeldanes, L. F. (1983). Effects of dietary cabbage, Brussels sprouts, Illicium verum, Schizandra chinensis and alfalfa on the benzo[a]pyrene metabolic system in mouse liver. Food and Chemical Toxicology 21, $479-486$.

Jakoby, W. B. (1978). The glutathione $S$-transferases: a group of multifunctional detoxification proteins. Advances in Enzymology 46, 383-414.

Jakoby, W. B. (1980). Enzymatic Basis of Detoxication, vol. 1. London: Academic Press.

Josefsson, E. (1970). Glucosinolate content and amino acid composition of rapeseed (Brassica napus) meal as affected by sulphur and nitrogen nutrition. Journal of the Science of Food and Agriculture 21, 98-103.

Kato, R. (1979). Characteristics and differences in the hepatic mixed function oxidases of different species. Pharmacology and Therapeutics 6, 41-98.

Kore, A. M., Jeffery, E. H. \& Wallig, M. A. (1993). Effects of 1-isothiocyanato-3-(methylsulfinyl)-propane on xenobiotic metabolizing enzymes in rats. Food and Chemical Toxicology 31, 723-729.

Krusius, F.-E. \& Peltola, P. (1966). The goitrogenic effect of naturally occurring L-5-vinyl and L-5-phenyl-2-thiooxazolidone in rats. Acta Endocrinologica 53, 342-352.

Langer, P. \& Greer, M. A. (1968). Antithyroid activity of some naturally occurring isothiocyanates in vitro. Metabolism 17, 596-605.

Langer, P. \& Michajlovskij, N. (1969). Studies on the antithyroid activity of naturally occurring L-5-vinyl-2thiooxazolidone and its urinary metabolite in rats. Acta Endocrinologica 62, 21-30.

Langer, P., Michajlovskij, N., Sedlák, J. \& Kutka, M. (1971). Studies on the antithyroid activity of naturally occurring L-5-vinyl-2-thiooxazolidone in man. Endokrinologie 57, 225-229.

Langer, P. \& Štolc, V. (1965). Goitrogenic activity of allylisothiocyanate - a widespread natural mustard oil. Endocrinology 76, 151-155.

Lanzani, A., Piana, G., Piva, G., Cardillo, M., Rastelli, A. \& Jacini, G. (1974). Changes in Brassica napus progoitrin induced by sheep rumen fluid. Journal of the American Oil Chemists' Society 51, 517-518.

Lehrmann, P. (1989). [Rapeseed: glucosinolate variability.] Cultivar 245, 44-46.

Lewis, J. \& Fenwick, G. R. (1987). Glucosinolate content of Brassica vegetables: analysis of twenty-four cultivars of calabrese (green sprouting broccoli, Brassica oleracea L. var. botrytis subvar. cymosa Lam.). Food Chemistry 25, 259-268

Lewis, J. \& Fenwick, G. R. (1988). Glucosinolate content of brassica vegetables - Chinese cabbages pe-tsai (Brassica pekinensis) and pak-choi (Brassica chinensis). Journal of the Science of Food and Agriculture 45, 379-386.

Linscheid, M., Wendisch, D. \& Strack, D. (1980). The structures of sinapic acid esters and their metabolism in cotyledons of Raphanus sativus. Zeitschrift für Naturforschung 35C, 907-914.

Lo, M.-T. \& Bell, J. M. (1972). Effects of various dietary glucosinolates on growth, feed intake, and thyroid function of rats. Canadian Journal of Animal Science 52, 295-302.

Lo, M. T. \& Hill, D. C. (1971). Effect of feeding a high level of rapeseed meal on weight gains and thyroid function of rats. Journal of Nutrition 101, 975-980.

Loub, W. D., Wattenberg, L. W. \& Davis, D. W. (1975). Aryl hydrocarbon hydroxylase induction in rat tissues by naturally occurring indoles of cruciferous plants. Journal of the National Cancer Institute 54, 985-988.

McDanell, R. E., McLean, A. E. M., Hanley, A. B., Heaney, R. K. \& Fenwick, G. R. (1987). Differential induction of mixed-function oxidase (MFO) activity in rat liver and intestine by diets containing processed cabbage: correlation with cabbage levels of glucosinolates and glucosinolate hydrolysis products. Food and Chemical Toxicology 25, 363-368.

McDanell, R. E., McLean, A. E. M., Hanley, A. B., Heaney, R. K. \& Fenwick, G. R. (1988). Chemical and biological properties of indole glucosinolates (glucobrassicins): a review. Food and Chemical Toxiology 26, 59-70.

McDanell, R. E., McLean, A. E. M., Hanley, A. B., Heaney, R. K. \& Fenwick, G. R. (1989). The effect of feeding Brassica vegetables and intact glucosinolates on mixed-function-oxidase activity in the livers and intestines of rats. Food and Chemical Toxicology 27, 289-293.

McMillan, M., Spinks, E. A. \& Fenwick, G. R. (1986). Preliminary observations on the effect of dietary Brussels sprouts on thyroid function. Human Toxicology 5, 15-19.

Mannervik, B. (1985). The isoenzymes of glutathione transferase. Advances in Enzymology 57, 357-417. 
Marangos, A. \& Hill, R. (1974). The hydrolysis and absorption of thioglucosides of rapeseed meal. Proceedings of the Nutrition Society $33,90 \mathrm{~A}$.

Michnovicz, J. J. \& Bradlow, H. L. (1991). Altered estrogen metabolism and excretion in humans following consumption of indole-3-carbinol. Nutrition and Cancer 16, 59-66.

Miguchi, S., Kojima, T. \& Fukuzawa, M. (1974). Goitrogenic substance in rapeseed. V. The myrosinase-like activity of intestinal bacteria of chickens. Journal of Food Science and Technology 21, 215-222.

Miller, K. W. \& Stoewsand, G. S. (1983). Hepatic polysubstrate monooxygenase activities in different strains of rats fed cabbage (Brassica oleracea). Drug and Chemical Toxicology 6, 93-110.

Mullin, W. J. \& Sahasrabudhe, M. R. (1978). An estimate of the average daily intake of glucosinolates via cruciferous vegetables. Nutrition Reports International 18, 273-279.

Muztar, A. J., Huque, T., Ahmad, P. \& Slinger, S. J. (1979). Effect of allyl isothiocyanate on plasma and urinary concentrations of some biochemical entities in the rat. Canadian Journal of Physiology and Pharmacology 57, 504-509.

Nebert, D. W., Nelson, D. R., Adesnik, M., Coon, M. J., Estabrook, R. W., Gonzalez, F. J., Guengerich, F. P., Gunsalus, I. C., Johnson, E. F., Kemper, B., Levin, W., Phillips, I. R., Sato, R. \& Waterman, M. R. (1989). The P450 superfamily: updated listing of all genes and recommended nomenclature for the chromsomal loci. DNA 8, 1-13.

Nishie, K. \& Daxenbichler, M. E. (1980). Toxicology of glucosinolates, related compounds (nitriles, $R$-goitrin, isothiocyanates) and vitamin $\mathrm{U}$ found in Cruciferae. Food and Cosmetic Toxicology 18, 159-172.

Nugon-Baudon, L., Rabot, S., Flinois, J. P., Beaune, P. \& Szylit, O. (1991). Glucosinolate interactions with the hepatic xenobiotic metabolizing enzymes (XME): influence of the intestinal microflora. In Proceedings of the GCIRC 8th International Rapeseed Congress, pp. 402-407 [McGregor, editor].

Nugon-Baudon, L., Rabot, S., Szylit, O. \& Raibaud, P. (1990a). Glucosinolates toxicity in growing rats: interactions with the hepatic detoxification system. Xenobiotica 20, 223-230.

Nugon-Baudon, L., Rabot, S., Wal, J.-M. \& Szylit, O. (1990b). Interactions of the intestinal microflora with glucosinolates in rapeseed meal toxicity : first evidence of an intestinal lactobacillus possessing a myrosinase-like activity in vivo. Journal of the Science of Food and Agriculture 52, 547-559.

Nugon-Baudon, L., Szylit, O. \& Raibaud, P. (1988). Production of toxic glucosinolate derivatives from rapeseed meal by intestinal microflora of rat and chicken. Journal of the Science of Food and Agriculture 43, $299-308$.

Oginsky, E. L., Stein, A. E. \& Greer, M. A. (1965). Myrosinase activity in bacteria as demonstrated by the conversion of progoitrin to goitrin. Proceedings of the Society for Experimental Biology and Medicine 119 , $360-364$.

Ohtsuru, M. \& Hata, T. (1979). The interaction of L-ascorbic acid with the active center of myrosinase. Biochimica et Biophysica Acta 567, 384-391.

Ozierenski, B., Plass, R. \& Lewerenz, H.-J. (1993). Effects of glucosinolate breakdown products on the hepatic biotransformation system in male rats. Nahrung 37, 5-14.

Pantuck, E. J., Hsiao, K.-C., Loub, W. D., Wattenberg, L. W., Kuntzman, R. \& Conney, A. H. (1976). Stimulatory effect of vegetables on intestinal drug metabolism in the rat. Journal of Pharmacology and Experimental Therapeutics 198, 278-283.

Pantuck, E. J., Pantuck, C. B., Anderson, K. E., Wattenberg, L. W., Conney, A. H. \& Kappas, A. (1984). Effect of Brussels sprouts and cabbage on drug conjugation. Clinical Pharmacology and Therapeutics 35, 161-169.

Pantuck, E. J., Pantuck, C. B., Garland, W. A., Min, B. H., Wattenberg, L. W., Anderson, K. E., Kappas, A. \& Conney, A. H. (1979). Stimulatory effect of Brussels sprouts and cabbage on human drug metabolism. Clinical Pharmacology and Therapeutics 25, 88-95.

Pence, B. C., Buddingh, F. \& Yang, S. P. (1986). Multiple dietary factors in the enhancement of dimethylhydrazine carcinogenesis: main effect of indole-3-carbinol. Journal of the National Cancer Institute 77, 269-276.

Pickett, C. B. \& Lu, A. Y. H. (1989). Glutathione $S$-transferases: gene structure, regulation, and biological function. Annual Review of Biochemistry 58, 743-764.

Quinsac, A. (1993). Les glucosinolates et leurs dérivés dans les crucifêres. Analyse par chromatographie en phase liquide et perspectives dutilisation de Télectrophorèse capillaire (Glucosinolates and glucosinolate derivatives in cruciferous plants. HPLC analysis and the possibilities of capillary electrophoresis), PhD Thesis, University of Orléans, $143 \mathrm{pp}$.

Rabot, S., Nugon-Baudon, L., Boutemine, Y., Raibaud, P. \& Szylit, O. (1990). Incidence of three human digestive bacterial strains on rapeseed meal toxicity in gnotobiotic rats. Microecology and Therapy 20, 135-140.

Rabot, S., Nugon-Baudon, L., Popot, F. \& Szylit, O. (1991). Preliminary studies on the modulation of rapeseed meal toxicity in conventional rats by poorly digestible carbohydrates. In Proceedings of the GCIRC 8th International Rapeseed Congress, pp. 1561-1566 [McGregor, editor].

Rabot, S., Nugon-Baudon, L., Raibaud, P. \& Szylit, O. (1993a). Rapeseed meal toxicity in gnotobiotic rats: influence of a whole human faecal flora or single human strains of Escherichia coli and Bacteroides vulgatus. British Journal of Nutrition 70, 323-331.

Rabot, S., Nugon-Baudon, L. \& Szylit, O. (1993b). Alterations of the hepatic xenobiotic-metabolizing enzymes by a glucosinolate-rich diet in germ-free rats: infuence of a pre-induction with phenobarbital. British Journal of Nutrition 70, 347-354.

Rowland, I. R. (1988). Interactions of the gut microflora and the host in toxicology. Toxicologic Pathology 16, 147-153. 
Salbe, A. D. \& Bjeldanes, L. F. (1989). Effect of diet and route of administration on the DNA binding of aflatoxin $\mathrm{B}_{1}$ in the rat. Carcinogenesis 10, 629-634.

Sang, J. P., Minchinton, I. R., Johnstone, P. K. \& Truscott, R. J. W. (1984). Glucosinolate profiles in the seed, root and leaf tissue of cabbage, mustard, rapeseed, radish and swede. Canadian Journal of Plant Science 64 , 77-93.

Searle, L. M., Chamberlain, K. \& Butcher, D. N. (1984). Preliminary studies on the effects of copper, iron and manganese ions on the degradation of 3-indolylmethyl-glucosinolate (a constituent of Brassica spp.) by myrosinase. Journal of the Science of Food and Agriculture 35, 745-748.

Searle, L. M., Chamberlain, K., Rausch, T. \& Butcher, D. N. (1982). The conversion of 3-indolylmethylglucosinolate to 3-indolylacetonitrile by myrosinase and its relevance to the clubroot disease of the Cruciferae. Journal of Experimental Botany 33, 935-942.

Sesardic, D., Pasanen, M., Pelkonen, O. \& Boobis, A. R. (1990). Differential expression and regulation of members of the cytochrome P450IA gene subfamily in human tissues. Carcinogenesis 11, 1183-1188.

Shertzer, H. G. (1982). Indole-3-carbinol and indole-3-acetonitrile influence on hepatic microsomal metabolism. Toxicology and Applied Pharmacology 64, 353-361.

Shertzer, H. G. (1983). Protection by indole-3-carbinol against covalent binding of benzo[ $a$ ]pyrene metabolites to mouse liver DNA and protein. Food and Chemical Toxicology 21, 31-35.

Shertzer, H. G. (1984). Indole-3-carbinol protects against covalent binding of benzo[a]pyrene and $N$ nitrosodimethylamine metabolites to mouse liver macromolecules. Chemico-Biological Interactions 48, 81-90.

Slominski, B. A. \& Campbell, L. D. (1989). Formation of indole glucosinolate breakdown products in autolyzed, steamed, and cooked Brassica vegetables. Journal of Agricultural and Food Chemistry 37, 1297-1302.

Sones, K., Heaney, R. K. \& Fenwick, G. R. (1984a). An estimate of the mean daily intake of glucosinolates from cruciferous vegetables in the UK. Journal of the Science of Food and Agriculture 35, 712-720.

Sones, K., Heaney, R. K. \& Fenwick, G. R. (1984b). Glucosinolates in Brassica vegetables. Analysis of twentyseven caulifiower cultivars (Brassica oleracea L. var. botrytis subvar. cauliflora DC). Journal of the Science of Food and Agriculture 35, 762-766.

Sparnins, V. L., Venegas, P. L. \& Wattenberg, L. W. (1982). Glutathione S-transferase activity: enhancement by compounds inhibiting chemical carcinogenesis and by dietary constituents. Journal of the National Cancer Institute 68, 493-496.

Srisangnam, C., Hendricks, D. G., Sharma, R. P., Salunkhe, D. K. \& Mahoney, A. W. (1980a). Effects of dietary cabbage (Brassica oleracea $\mathbf{L}$.) on the tumorigenicity of 1,2-dimethylhydrazine in mice. Journal of Food Safety 2, 235-245.

Srisangnam, C., Salunkhe, D. K., Reddy, N. R. \& Dull, G. G. (1980b). Quality of cabbage. II. Physical, chemical, and biochemical modification in processing treatments to improve flavor in blanched cabbage (Brassica oleracea L.). Journal of Food Quality 3, 233-250.

Srivastava, V. K., Philbrick, D. J. \& Hill, D. C. (1975). Response of rats and chicks to rapeseed meal subjected to different enzymatic treatments. Canadian Journal of Animal Science 55, 331-335.

Stoewsand, G. S., Anderson, J. L. \& Munson, L. (1988). Protective effect of dietary Brussels sprouts against mammary carcinogenesis in Sprague-Dawley rats. Cancer Letters 39, 199-207.

Stoewsand, G. S., Babish, J. B. \& Wimberly, H. C. (1978). Inhibition of hepatic toxicities from polybrominated biphenyls and aflatoxin $\mathrm{B}_{1}$ in rats fed cauliflower. Journal of Environmental Pathology and Toxicology 2 , 399-406.

Szabo, S., Bailey, K. A., Boor, P. J. \& Jaeger, R. J. (1977). Acrylonitrile and tissue glutathione: differential effect of acute and chronic interactions. Biochemical and Biophysical Research Communications 79, 32-37.

Tanaka, T., Mori, Y., Morishita, Y., Hara, A., Ohno, T., Kojima, T. \& Mori, H. (1990). Inhibitory effect of sinigrin and indole-3-carbinol on diethylnitrosamine-induced hepatocarcinogenesis in male $A C I / N$ rats. Carcinogenesis 11, 1403-1406.

Tani, N., Ohtsuru, M. \& Hata, T. (1974). Isolation of myrosinase producing microorganism. Agricultural and Biological Chemistry 38, 1617-1622.

Timms, C., Schladt, L., Robertson, L., Rauch, P., Schramm, H. \& Oesch, F. (1987). The regulation of rat liver epoxide hydrolases in relation to that of other drug-metabolizing enzymes. In Drug Metabolism: From Molecules to Man, pp. 55-68 [D. Benford, J. W. Bridges and G. G. Gibson, editors]. London: Taylor and Francis.

Tookey, H. L. (1973). Crambe thioglucoside glucohydrolase (EC 3.2.3.1): separation of a protein required for epithiobutane formation. Canadian Journal of Biochemistry 51, 1654-1660.

Tookey, H. L. \& Wolff, I. A. (1970). Effect of organic reducing agents and ferrous ion on thioglucosidase activity of Crambe abyssinica seed. Canadian Journal of Biochemistry 48, 1024-1028.

Uda, Y., Kurata, T. \& Arakawa, N. (1986). Effects of pH and ferrous ion on the degradation of glucosinolates by myrosinase. Agricultural and Biological Chemistry 50, 2735-2740.

Ullrich, D. \& Bock, K. W. (1984). Glucuronide formation of various drugs in liver microsomes and in isolated hepatocytes from phenobarbital- and 3-methylcholanthrene-treated rats. Biochemical Pharmacology 33, 97-101.

VanEtten, C. H., Daxenbichler, M. E., Peters, J. E. \& Tookey, H. L. (1966). Variation in enzymatic degradation products from the major thioglucosides in Crambe abyssinica and Brassica napus seed meals. Journal of Agricultural and Food Chemistry 14, 426-430. 
VanEtten, C. H., Daxenbichler, M. E. \& Wolff, I. A. (1969). Natural glucosinolates (thioglucosides) in foods and feeds. Journal of Agricultural and Food Chemistry 17, 483-491.

Vermorel, M., Davicco, M.-J. \& Evrard, J. (1987). Valorization of rapeseed meal. 3. Effects of glucosinolate content on food intake, weight gain, liver weight and plasma thyroid hormone levels in growing rats. Reproduction, Nutrition, Développement 27, 57-66.

Vermorel, M. \& Evrard, J. (1987). Valorization of rapeseed meal. 4. Effects of iodine, copper and ferrous salt supplementation in growing rats. Reproduction, Nutrition, Développement 27, 769-779.

Vermorel, M., Heaney, R. K. \& Fenwick, G. R. (1986). Nutritive value of rapeseed meal: effects of individual glucosinolates. Journal of the Science of Food and Agriculture 37, 1197-1202.

Wattenberg, L. W. (1971). Studies of polycyclic hydrocarbon hydroxylases of the intestine possibly related to cancer. Effect of diet on benzpyrene hydroxylase activity. Cancer 28, 99-102.

Wattenberg, L. W., Hanley, A. B., Barany, G., Sparnins, V. L., Lam, L. K. T. \& Fenwick, G. R. (1986). Inhibition of carcinogenesis by some minor dietary components. In Diet, Nutrition and Cancer, pp. 13-21 [Y. Hayashi et al. editors]. Tokyo: VNU Science.

Wattenberg, L. W. \& Loub, W. D. (1978). Inhibition of polycyclic aromatic hydrocarbon-induced neoplasia by naturally-occurring indoles. Cancer Research 38, 1410-1413.

Wishart, G. J. (1978). Demonstration of functional heterogeneity of hepatic uridine diphosphate glucuronosyltransferase activities after administration of 3-methylcholanthrene and phenobarbital to rats. Biochemical Journal 174, 671-672.

Wortelboer, H. M. (1991). Primary hepatocyte cultures as a model system for the determination of induction of biotransformation enzymes. Effects of glucosinolate hydrolysis products. $\mathrm{PhD}$ Thesis, University of Utrecht, $145 \mathrm{pp}$.

Wortelboer, H. M., de Kruif, C. A., van Iersel, A. A. J., Noordhoek, J., Blaauboer, B. J., van Bladeren, P. J. \& Falke, H. E. (1992). Effects of cooked Brussels sprouts on cytochrome P-450 profile and phase II enzymes in liver and small intestinal mucosa of the rat. Food and Chemical Toxicology 30, 17-27.

Wrighton, S. A., Campanile, C., Thomas, P. E., Maines, S. L., Watkins, P. B., Parker, G., Mendez-Picon, G., Haniu, M., Shively, J. E., Levin, W. \& Guzelian, P. S. (1986). Identification of a human liver cytochrome P-450 homologous to the major isosafrole-inducible cytochrome P-450 in the rat. Molecular Pharmacology 29, 405-410.

Youngs, C. G. \& Perlin, A. S. (1967). Fe(II)-catalyzed decomposition of sinigrin and related thioglycosides. Canadian Journal of Chemistry 45, 1801-1804.

Zhang, Y., Talalay, P., Cho, C.-G. \& Posner, G. H. (1992). A major inducer of anticarcinogenic protective enzymes from broccoli: isolation and elucidation of structure. Proceedings of the National Academy of Sciences, USA 89, 2399-2403. 